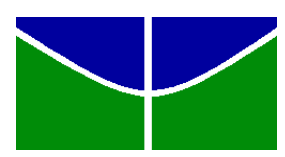

UNIVERSIDADE DE BRASÍLIA INSTITUTO DE CIÊNCIAS HUMANAS

DEPARTAMENTO DE GEOGRAFIA

PROGRAMA DE PÓS-GRADUAÇÃO EM GEOGRAFIA

\title{
ANÁLISE GEOMORFOLOGICA E GEOTÉCNICA EM ENCOSTAS SUSCETÍVEIS A PROCESSOS EROSIVOS - BACIA HIDROGRÁFICA DO RIBEIRÃO CONTAGEM- DF
}

LIGIER MODESTO BRAGA

BRASÍLIA - DF: SETEMBRO DE 2015 
Universidade de Brasília

Instituto de Ciências Humanas

Departamento de Geografia

Programa de Pós-Graduação em Geografia

UNIVERSIDADE DE BRASÍLIA

PÓS-GRADUAÇÃO EM GEOGRAFIA

\section{ANÁLISE GEOMORFOLOGICA E GEOTÉCNICA EM ENCOSTAS SUSCETÍVEIS A PROCESSOS EROSIVOS - BACIA HIDROGRÁFICA DO RIBEIRÃO CONTAGEM- DF}

Ligier Modesto Braga

Orientador:

Rogério Elias Soares Uagoda

Có-orientador

Hernán Carvajal

Dissertação de MestradoBrasília-DF

Setembro de 2015 
Universidade de Brasília

Instituto de Ciências Humanas

Departamento de Geografia

Programa de Pós-Graduação em Geografia

UNIVERSIDADE DE BRASÍLIA

PÓS-GRADUAÇÃO EM GEOGRAFIA

\title{
ANÁLISE GEOMORFOLOGICA E GEOTÉCNICA EM ENCOSTAS SUSCETÍVEIS A PROCESSOS EROSIVOS - BACIA HIDROGRÁFICA DO RIBEIRÃO CONTAGEM- DF
}

\author{
Ligier Modesto Braga
}

Dissertação de Mestrado submetida ao Departamento de Geografia da Universidade de Brasília, como parte dos requisitos necessários para a obtenção do Grau de Mestre em Geografia, área de concentração Gestão Ambiental e Territorial, opção Acadêmica.

Aprovado por:

Rogério Elias Soares Uagoda, Doutor (Dept. de Geografia - UnB)

(Orientador)

Osmar Abílio de Carvalho Júnior, Doutor (Dept. de Geografia - UnB)

(Examinador Interno)

André de Sousa Avelar, Doutor (Dept. de Geografia - UFRJ)

(Examinador Externo)

Brasília-DF, 1 de Setembro de 2015. 
Universidade de Brasília

Instituto de Ciências Humanas

Departamento de Geografia

Programa de Pós-Graduação em Geografia

\section{BRAGA, LIGIER MODESTO.}

Análise geomorfológica e geotécnica em encostas suscetíveis a movimentos de massa - bacia hidrográfica do Ribeirão Contagem, n p., 297 mm, (UnB-GEA, Mestre, Análise de Sistemas Naturais, 2015).

Dissertação de Mestrado - Universidade de Brasília. Departamento de Geografia.

1. Geomorfologia de encosta

2. Resistência ao Cisalhamento

3. Movimentos de massa

4. Sedimentos de encosta

I. UnB-GEA

É concedida à Universidade de Brasília permissão para reproduzir cópias desta dissertação e emprestar ou vender tais cópias somente para propósitos acadêmicos e científicos. O autor reserva outros direitos de publicação e nenhuma parte desta dissertação de mestrado pode ser reproduzida sem a autorização por escrito do autor. 
DEDICATÓRIA

Á minha mãe, pelo amor, apoio e dedicação, incondicionais.

Ao Felipe, pela cumplicidade. 


\section{RESUMO}

Os movimentos de massa compõem uma parte dos fenômenos naturais que mais tem causado prejuízos, no mundo. $\mathrm{O}$ material transportado e depositado nas encostas em consequência de um movimento de massa, pode ser reconhecido por um número de características granulométricas, morfométricas e micromorfológicas, da encosta. Este trabalho objetivou caracterizar os solos de três encostas de uma pequena área da bacia do ribeirão Contagem, a partir de dados geomorfológicos, e sedimentológicos, e, vincular esses resultados ao conjunto de tensões presentes nos materiais dessas vertentes, para conhecer suas condições de estabilidade e propensão a movimentos de massa. Foram traçadas três topossequências para investigação dos materiais presentes em encostas de morfologias distintas (concavidade fechada, concavidade aberta, e encosta convexo-retilínea), onde foi utilizado um trado manual. Foram coletadas 6 amostras indeformadas, em porções distintas das encostas. Através de testes de cisalhamento direto, foram aferidos coesão e ângulo de atrito e calculada a resistência dos materiais. Distinguem-se na área de estudo, três patamares de deposição bem delimitados que conferem comportamentos distintos para cada porção da encosta e fundo de vale. Obtiveram-se altos valores de resistência ao cisalhamento para todas as porções das encostas, sendo que a convexo-retilínea apresentou a maior $(68,11 \mathrm{kPa})$. Os testes revelaram baixa coesão e angulo de atrito na área o vale. As curvas de ruptura apresentaram altas tensões cisalhantes suportadas pelos solos da encosta convexa, em detrimento das demais. A estabilidade dos materiais averiguada por esta pesquisa admite dizer que a ocorrência de fenômenos de deslizamento na bacia do ribeirão Contagem não estão predominantemente ligadas às características mecânicas dos materiais que as compõe. O que as análises geomorfológicas por sua vez nos intuem, é a existência pretérita da condição de eventos mais fortes que geraram as cicatrizes e deposições, observadas atualmente. 


\section{SUMÁRIO}

LISTA DE FIGURAS ............................................................. vii

LISTA DE ABREVIATURAS E SIGLAS ......................................... ix

1 INTRODUÇÃ

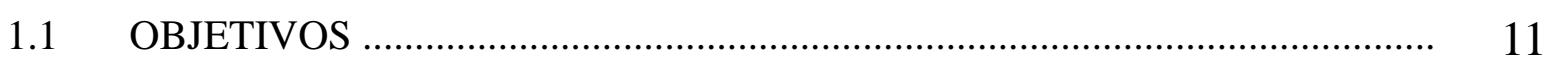

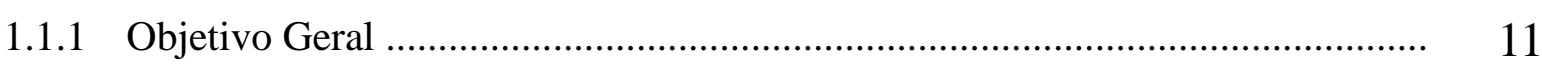

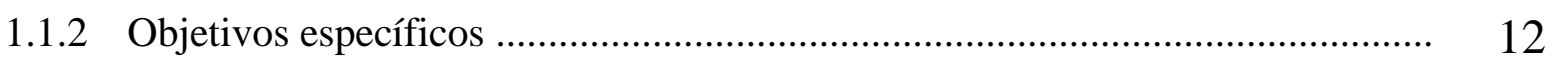

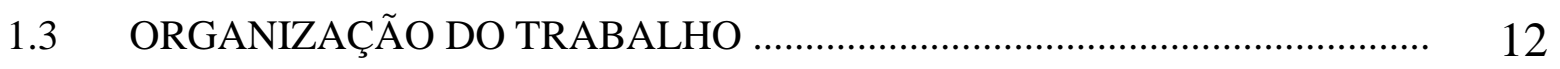

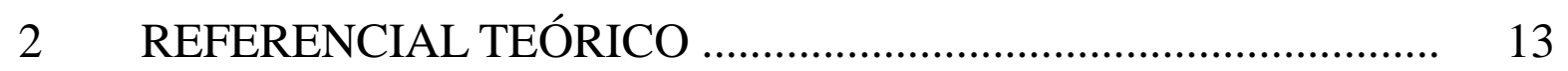

2.1 GEOMORFOLOGIA DE ENCOSTA ....................................................... 13

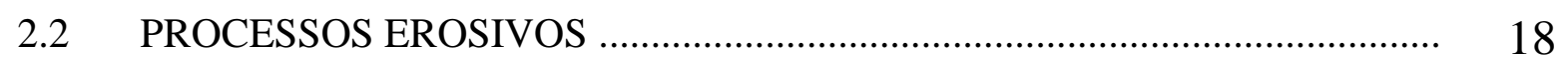

2.2.1 Movimentos de Massa ................................................................................. 20

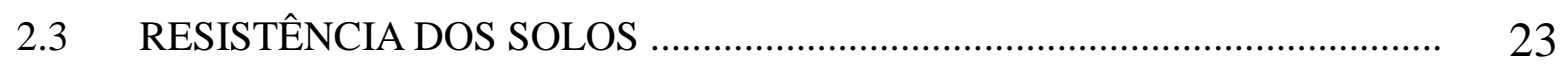

3 ANÁlisE GEOMORFOLÓGICA E GEOTÉCNICA EM ENCOSTAS SUSCETÍVEIS A DESLIZAMENTOS ROTACIONAIS DE SOLOS NA BACIA DO RIBEIRÃO CONTAGEM - DF

REFERÊNCIAS BIBLIOGRÁFICAS ............................................. 59

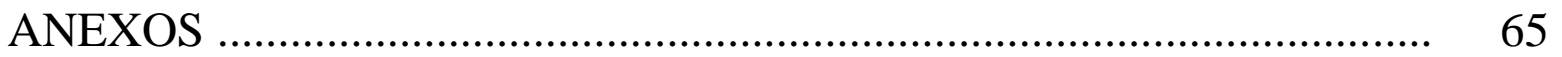




\section{LISTA DE FIGURAS}

Figura 1 - Representação dos critérios de ruptura: (a) de Coulomb e (b) de Mohr. 26

Figura 2 - Mapa da área e mapa de declividade do canal fluvial que passa pela fazenda Buraco

Figura 3: Mapa da área da fazenda Buraco. 34

Figura 4 - Fotos do deslizamento rotacional na fazenda Buraco 35

Figura 5 - Perfis verticais da E1 38

Figura 6 - Gráfico granulométrico da E1 .39

Figura 7 - Perfil lateral da concavidade fechada - E1

Figura 8 - Gráficos de comparação de comportamento do colúvio ( E1)

Figura 9 - Morfoscopia dos grãos de areia dos pontos P1, P8 e P11 da E1 (modificado de Caldeira,2015)

Figura 10 - Gráficos de comparação de comportamento de alúvio (E1).

Figura 11 - Triangulo granulométrico E1

Figura 12 - Gráficos das curvas de ruptura da E1

Figura 13- Resistência ao cisalhamento na porções da E1 e fundo de vale

Figura 14 - Fator de segurança da E1 45

Figura 15 - Perfis verticais da E2 46

Figura 16 - Curvas granulométricas da E2 47

Figura 17 - Perfil lateral da E2 48

Figura 18 - Gráfico de comparação de comportamento de alúvios da E2. 49

Figura 19 - Triangulo granulométrico E2 50

Figura 20 - Gráficos da curva de ruptura das amostras da E2 51

Figura 21- Gráfico da curva de ruptura encontrado na área de vale. 51

Figura 22 - Resistência ao cisalhamento na E2 52 


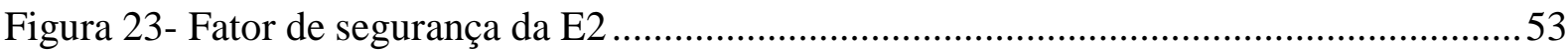

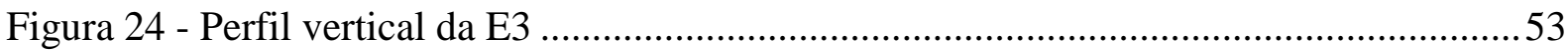

Figura 25 - Gráfico Histograma da granulometria da E3 .....................................................54

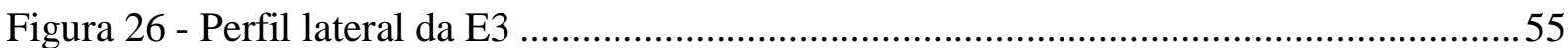

Figura 27 - Gráfico granulométrico da encosta convexa - E3 ................................................55

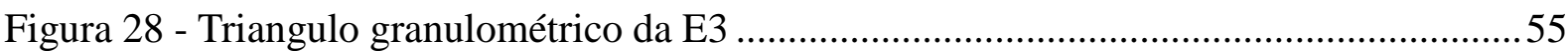

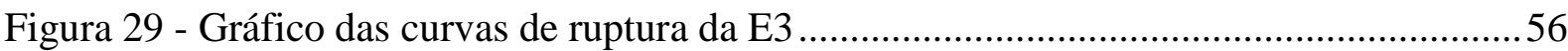

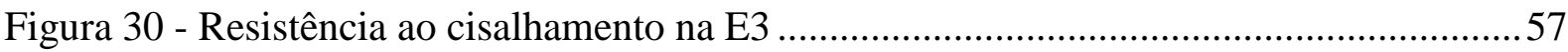




\section{LISTA DE ABREVIATURAS E SIGLAS}

$\begin{array}{ll}\mathrm{cm} & \text { Centímetros } \\ \mathrm{DF} & \text { Distrito Federal } \\ \mathrm{g} & \text { Grama } \\ { }^{\circ} \mathrm{C} & \text { Graus Celsius } \\ \text { Infralab } & \text { Laboratório de Estruturas e Construção Civil } \\ \text { LAGEF } & \text { Laboratório de Geografia Física } \\ \text { L } & \text { Litro } \\ \mathrm{m} & \text { Metro } \\ \text { mm } & \text { Milímetro } \\ \text { mL } & \text { Milílitro } \\ \text { MVRC } & \text { Médio vale do ribeirão Contagem } \\ \text { PPGEA } & \text { Programa de Pós-Graduação em Geografia } \\ \text { RA } & \text { Região Administrativa } \\ \text { RPM } & \text { Rotações por minuto } \\ \text { SEDEC/DF } & \text { Secretaria de Defesa Civil do DF } \\ \text { TFSA } & \text { Terra Fina Seca ao Ar } \\ \text { UnB } & \text { Universidade de Brasília } \\ \text { E1 } & \text { Encosta côncava fechada } \\ \text { E2 } & \text { Encosta côncava aberta } \\ \text { E3 } & \text { Encosta convexo-retilínea }\end{array}$




\section{INTRODUÇÃO GERAL}

Movimentos de massa, mais conhecidos como deslizamentos de terra (FERNANDES \& AMARAL,1997), são responsáveis por 14\% dos prejuízos e $0,54 \%$ das mortes por fenômenos naturais no mundo, segundo estimativas (BONACHEA, 2006; CHOWDHURY, 2010).

No Brasil, as últimas décadas vem sendo fortemente marcadas por esses eventos, que ocorrem em áreas montanhosas e costeiras, e com consequências cada vez mais drásticas do ponto de vista ambiental, social e econômicos. O comprometimento da integridade humana, porém, pode ser considerado umas das maiores perdas, frente a esse tipo de desastre. Os estados de Santa Catarina, Paraná, São Paulo, Minas Gerais, Rio de Janeiro, Espírito Santo, Bahia, Sergipe, Alagoas, Pernambuco, e Paraíba são os mais atingidos por deslizamentos (KOBIYAMA et al., 2006). Neles, houveram enormes prejuízos, sendo que há uma concentração da ocorrência de desastres na Serra do Mar. Em geral, esses fenômenos são relacionados a fatores naturais como precipitação pluviométrica extraordinária e/ou frágeis condições geológicas e geotécnicas de solo e rocha, e é comum também estarem associados a alguma contribuição antrópica como desmatamento e águas residuais (esgoto).

No Distrito Federal, a ocorrência destes eventos e sua propensão é consideravelmente menor, comparado aos estados citados. Isso se deve ao relevo, em geral mais aplainado, já que no período de chuva temos um regime pluviométrico muitas vezes parecido com os dos estados citados. Mesmo com baixo número de desastres por deslizamentos, registradas no DF, é crescente o número de áreas consideradas suscetíveis, o que não anula as preocupações de ocorrência de um evento catastrófico e suas consequências para a população.

Entre outubro de 2010 e março de 2011 a Defesa Civil do DF (SEDEC/DF) fez 55 notificações e 39 interdições de residência, já entre outubro de 2011 e março de 2012 foram 206 notificações e 53 interdições. Em mapeamento feito pela Secretaria de Defesa Civil em 2011 no DF, foram mapeadas 26 áreas consideradas de risco, onde se distribuíam aproximadamente 1750 pessoas, em 11 das 31 Regiões Administrativas do DF. Em outubro de 2012, um levantamento do mesmo órgão, indicou que 3,4 mil pessoas vivem em 860 casas em área de "alto risco" de deslizamentos e desabamentos, no DF. As residências se localizam em 37 pontos de 16 RA's, em solo arenoso, argiloso ou próximo a encostas ou á beira de rios, 
sendo a maioria composta por ocupações irregulares. No contexto desse último levantamento, a Fercal é a R.A com maior número de pontos (7) de residências em área de risco.

A bacia hidrográfica do Ribeirão Contagem, onde está inserida a Região Administrativa da Fercal, ocupa uma região geomorfologicamente distinta do restante do DF, onde pode ser observada uma evidente suscetibilidade frente aos processos erosivos, dada a sua declividade, elevação, e grau de dissecação (BRAGA, 2013). Esse cenário expressa uma situação potencial de risco, haja vista que $55 \%$ das feições erosivas (movimentos de massa não foram incluídos) mapeadas na área encontram-se em áreas de alto potencial erosivo, segundo Santos (2013) , além de serem áreas de crescente número de habitações desordenadas. As encostas escolhidas para esse trabalho estão localizadas na Fazenda Buraco, área próxima a movimento de massa e limítrofe a área de expansão de ocupações irregulares de alta densidade.

Esta pesquisa pretende trabalhar de forma integrada os conhecimentos geomorfológicos e geotécnicos, com o intuito de melhorar a compreensão dos sistemas ambientais estudados e diminuir as incertezas de suas análises. Está, pois, vinculada ao Laboratório de Geografia Física, do Departamento de Geografia, da Universidade de Brasília, no âmbito do Grupo de Pesquisas de Processos Geomorfológicos e Evolução da Paisagem, coordenado pelo professor Rogério Uagoda, e envolvendo alunos de PIBIC e Mestrado em pesquisas articuladas.

O projeto teve apoio parcial da Universidade de Brasília, por meio da diretoria de transporte, a qual possibilitou grande parte das saídas de campo para coletas de amostras. Foram utilizados recursos do Laboratório de Geografia Física, Laboratório de Infraestrutura da Faculdade de Engenharia Civil, e Laboratório de Geotecnia.

\subsection{OBJETIVOS}

\subsubsection{Objetivo Geral:}

Caracterizar os solos para conhecer os aspectos geomorfológicos e geotécnicos que influenciam na estabilidade das encostas sujeitas a deslizamentos.

\subsubsection{Objetivos específicos:}


- Estudar as características da morfologia superficial em área do médio vale do ribeirão Contagem, procurando estabelecer paralelos entre processos geradores;

- Estudar os condicionantes litológicos e de solo nas encostas e fundos de vales;

- Estudar a resistência ao cisalhamento dos materiais in situ e transportados, em diferentes trechos das encostas estudadas;

\subsection{ORGANIZAÇÃO DO TRABALHO}

Esta dissertação é apresentada em formato de artigo. Compõe-se de uma introdução geral, no primeiro capitulo; o referencial teórico constitui o segundo capitulo; o terceiro capítulo refere-se ao artigo propriamente dito, o qual será submetido à Revista Brasileira de Geomorfologia. Este por sua vez, contém introdução, materiais e métodos, resultados e discussão, conclusão e bibliografia, nele estão apresentados as análises dos resultados obtidos, assim como o que se concluiu com a pesquisa. Em anexo, está a metodologia detalhada da pesquisa. 


\section{REFERENCIAL TEÓRICO}

\subsection{GEOMORFOLOGIA DE ENCOSTA}

O entendimento de uma dada paisagem depende de compreender a interdependência dos componentes e relações que dela fazem parte, formando de maneira sistêmica um todo unificado. As características do meio definirão os diferentes contextos sob os quais uma paisagem irá se desenvolver, sejam elas: pedológicas, geológicas, geomorfológicas, ecológicas e sociais.

A relação dos atributos da paisagem com os solos vem sendo amplamente estudada (MARTINS et all 2007; QUEIROZ-NETO 2011; REATTO et all 2005) considerando por vezes o conceito de que os perfis de solos sucedem-se nas vertentes e apresentam uma relação genética em diferentes formas de relevo. Este é o conceito de Catena, a partir do qual foram desenvolvidas várias abordagens metodológicas, levando sempre em consideração as polaridades das vertentes como unidade de observação.

A idéia de Catena é relevante para este estudo, que pretende conhecer os perfis do solo ao longo de um eixo lateral, as diferenciações das camadas e seu arranjo estrutural, concordantemente à observação e análise do modelado das encostas e suas características morfométricas.

A disposição dos sedimentos formando camadas com diferentes permeabilidades gera um mecanismo de instabilização, com caminhos preferenciais de água, como pode ser demonstrado por Santana \& Coutinho (2006) em relação a um deslizamento ocorrido em 2005 no Recife. Com este mesmo intuito, a presente pesquisa se dedica à descrição dos contatos solo/rocha/saprolito, assim como o limite de cada camadas de material pedogenisado, na tentativa de evidenciar possíveis mecanismos de instabilização nas encostas da bacia do ribeirão Contagem.

A identificação de vários tipos de materiais na encosta é importante na geomorfologia. Geralmente, diversos processos são envolvidos no desenvolvimento de uma encosta, refletindo diversificadas condições ambientais no tempo e no espaço. A importância de se identificar as feições resultantes dos diversos tipos de trabalho nas encostas ao longo do tempo vem também da necessidade de compreender os possíveis re-trabalhamentos 
recorrentes, a que podem estar sujeitas essas feições e como eles afetam o nosso ambiente nos dias atuais.

Articular a geometria de superfície com a das unidades deposicionais do substrato, numa perspectiva tridimensional, constitui a concepção básica de estudos que tem procurado explicar a evolução das encostas com base em argumentos de cunho estratigráfico e geomorfológico (Moura \& Meis, 1980)

A interpretação das relações entre a evolução pedogenética e do relevo, nas últimas décadas, vem sendo subsidiadas pela abordagem tridimensional dos sistemas de encosta. Assim as relações geométricas (planta x perfil), acopladas à estrutura subsuperficial, individualizam unidades definidas por Huggest (1975 apud MOURA et al.,1991) como Soil Landscape Systems (Sistemas Solo-Paisagem).

A primeira pergunta que se faz ao estudar os solos nas encostas é se o material é in situ ou transportado. Um número de feições macroscópicas pode ser útil para estabelecer a presença de material translocado nas encostas tais como: a estratificação, a repetição das mesmas sequências de horizontes do solo que recobrem um ao outro, e linhas de pedra (MUCHER et al, 2010).

Em estudo sobre a função das subdivisões morfométricas do terreno frente a suscetibilidade a movimentos de massa, no Maciço da Tijuca, Coelho Netto et al (2006) atribuiu que áreas com declividade $>10^{\circ}$, são consideradas com potencial deposicional; áreas côncavas com declividade de $10-20^{\circ}$ correspondem a fundos de vale, onde depósitos coluviais permanecem estáveis; entre $15^{\circ}$ e $17^{\circ}$ os lençóis freáticos rasos tendem a favorecer a ocorrência de rastejamentos; encostas convexo-retilíneas $>35^{\circ}$ também associam-se com alto potencial de deslizamentos.

Levando em conta esses critérios, um mapeamento feito por Santos (2013), para a bacia do ribeirão Contagem, utilizou a curvatura do terreno (côncavo, retilíneo e convexo) e a declividade crítica para demonstrar áreas de alto e baixo potencial erosivo, e que recobrem, portanto, áreas com potencial de iniciação aos movimentos de massa.

Dentre os poucos estudos realizados na bacia do ribeirão Contagem, um mapeamento de feições erosivas, identificou diversos ravinamentos e voçorocamentos ligados diretamente ao crescimento da rede de drenagem (por erosão remontante), principalmente por canais de primeira ordem (BRAGA, 2013). Isso indica a intensidade de dissecação do relevo na área da 
bacia visto que ravinamentos e voçorocamentos se correlacionam a movimentos de massa (KUKEMILKS \& SAKS, 2013). A morfometria também é um condicionante dos movimentos de massa, já que a declividade, amplitude do relevo, aspecto e outras, são variáveis com papel importante na compreensão desses eventos.

Pretende-se com esse estudo, qualificar os controles de natureza geomorfológica que influenciam na vulnerabilidade do sistema encosta.

As relações entre classes de solo e condições ambientais são observadas na paisagem e representadas por diversos fatores como: clima, relevo, cobertura vegetal, declividade, tipo da vertente, material originário, drenagem superficial e interna e uso antrópico (PALMIERI \& LARACH, 1996). Dentre esses fatores, o desenvolvimento dos solos é fortemente influenciado pelo relevo, isso por que a configuração de um dado terreno orientará as condições hídricas do solo.

Reconhecer as características dos solos, dos arranjos geométricos entre os horizontes permite a espacialização da dinâmica da circulação interna da água vertical, e lateralmente, e determina a movimentação de matéria possibilitando compreender a evolução dos solos e das vertentes. (QUEIROZ NETO, 2011)

Sabe-se que os solos apresentam diferenciações laterais principalmente ao longo das encostas e o principal fator responsável pela sucessão sistemática deles ao longo das vertentes, segundo o conceito de catena (MILNE, 1934), é a erosão. Queiroz Neto (2002) explica que essas diferenciações não se manifestam simultaneamente em todos os horizontes presentes, logo, os solos não se sucedem apenas verticalmenete, como se observa numa trincheira, mas também lateralmente.

Segundo Braszczynski (1997), a forma da superfície terrestre é fundamental para o entendimento dos processos e transformações que ocorrem em um terreno, influenciando o fluxo d'água e o transporte de sedimentos. Para entender o processo de aceleração ou desaceleração do fluxo de água é importante identificar as formas do relevo, sejam elas: côncavas, retilíneas e convexas.

As formas do relevo são tidas como um forte fator controlador da drenagem e, consequentemente, da erosão. As concavidades, convexidades ou formas geométricas retilíneas, resultam da ação de processos erosivos e /ou deposicionais ao longo do tempo, e condicionam igualmente a ação dos processos erosivos e/ou deposicionais subsequentes 
(COELHO NETTO, 1994). Hack \& Goodlett (1960), perceberam que o direcionamento dos fluxos da água no solo está relacionado diretamente com a geometria das encostas: sobre as formas côncavas atua a convergência de fluxos, ao passo que, sobre as formas convexas atua a divergência.

As cabeceiras de drenagem têm em comum a topografia côncava (para cima), no entanto podem variar em suas características morfológicas, tamanho, profundidade e declividade (COELHO NETTO, 2003). A concavidade principal dessas cabeceiras pode receber convergência de fluxo de concavidades menores, que a alimenta. São caracterizadas por uma feição incisa na porção superior e uma deposicional ao longo da porção médioinferior, formando uma camada espessa de sedimentos ao longo da área de deposição. Essas unidades côncavas foram denominadas por Meis \& Monteiro (1979) como"rampas", as quais passam por ciclos de retrabalhamento de seus depósitos, formando os chamados complexos de rampa. Na porção em que se sobrepõem os sedimentos da encosta com os sedimentos fluviais, ao longo de intensas variações climáticas, interdígitam-se colúvios e alúvio-colúvios com os depósitos dos rios principais, formando o que veio a ser chamado rampa-terraços (MACHADO \& MOURA, 1982).

Segundo Coelho Netto (2003), a ação erosiva de canais fluviais ou cortes de estrada provocam descalçamento da base de encostas causando deslizamentos, que por sua vez propiciam a formação inicial de concavidades do tipo aberta. Esse seria o estágio inicial de sua esculturação, em que são caracteristicamente instáveis e apresentam limites agudos em seus contornos. Já uma condição geologicamente recente de estabilidade é indicada por convexidade na borda externa da concavidade, além de suavização na mudança interna de declives. Outro tipo de concavidade é associada ao controle das estruturas geológicas subjacentes, por isso denominada concavidade estrutural, subdividindo-se ainda em suspensas - próximas aos divisores de água - ou ajustadas, aquelas ligadas ao fundo do vale fluvial principal. No mesmo estudo, que trata da evolução de cabeceiras de drenagem e formação de concavidades sob controle estrutural no médio vale do Rio Paraíba do Sul, a autora depreende que não bastariam elementos físicos para explicar a evolução dos vales de cabeceira, e explicita a demanda de melhor compreender a influência dos processos químicos no controle da formação e comportamento hidráulico e mecânico diferencial dos solos.

Analisando a geometria das encostas dos desastres ocorridos no Maciço da Tijuca, no Rio de Janeiro em fevereiro de 1996 e abril de 2010, Coelho Netto et al. (2012) observou que 
61\% dos deslizamentos de 1996 concentraram-se ou convergiram para as áreas de topografia côncava, que correspondem aos fundos de vales das cabeceiras de drenagem e 39\% ocorreram em encostas retilíneas ou convexas, ao passo que em 2010 apenas $42 \%$ dos casos de deslizamentos ocorreram em encostas côncavas e $58 \%$ distribuiu-se em encostas convexas retilíneas.

Sobre variabilidade dos atributos do solo em relação as formas de relevo: SANCHEZ (2009), concluiu que os atributos do solo demonstram dependência espacial para concavidades e convexidades. Neste caso, as concavidades demonstraram maior variabilidade espacial para os atributos físicos( espessura do solo) e químicos(teor de argila e CTC) e fatores de erosão(risco de erosão), o que significa dizer que solos sujeitos á erosão não tem relação muito forte com áreas côncavas.

Sabe-se que as concavidades comportam maior convergência de fluxos de água, e esse fato, segundo Resende et al. (1997) pode interferir na maior variabilidade dos atributos. Sobre as covexiddades, Sanchez (2009) atesta que os valore médios de perda de solo, o potencial natural de erosão e risco de erosão são maiores, indicando maior suscetibilidade à erosão quando comparada às pedoformas côncavas.

Desse modo, o estudo do relevo mostra-se importante para a preservação do equilíbrio ambiental e organização da paisagem, já que este pode condicionar a distribuição espacial dos solos (Souza et al., 2004; Nizeyimana \& Bicki., 1992; Resende et al., 1997; Vasconcelos et al., 2012; Chagas et al., 2013).

A morfometria, além das formas das vertentes, também é um condicionante geomorfológico dos movimentos de massa, já que a declividade, amplitude do relevo, dissecação, aspecto e outras, são variáveis com papel importante na compreensão desses eventos. Em regiões tropicais úmidas o relevo sofre forte influência da drenagem, especialmente no modelamento das formas das vertentes e dos vales (MEIJERINK, 1988). A densidade de drenagem é a somatória do comprimento dos canais dividido pela área drenada por esses canais, cujo resultado demonstra a intensidade da dissecação do relevo. Autores como Chorley (1984) e Clowes \& Comfort (1986), consideram os canais perenes e também os ravinamentos no cálculo da densidade de drenagem.

Quanto maior o grau de inclinação de uma vertente maior a chance dos processos erosivos se acentuarem. A declividade é um fator que interfere de maneira direta no 
escoamento superficial, sendo função inversa da infiltração da água no solo (CUNHA, 1991). Na ocorrência de um movimento de massa a capacidade de deslocamento e transporte do material sólido ou líquido e sua velocidade são diretamente proporcionais à declividade. Christofolletti (1974), atenta para a importância dessa variável na atividade dos cursos d'água e no deslocamente do colúvio. O alto potencial de erosividade do canal se deve portanto ao gradiente de energia gerado por elevadas declividades (CHRISTOFOLETTI, 1981). Nesse contexto, regiões com alta densidade de drenagem e alta declividade são mais favoráveis a risco de escorregamento, como já apontado por Tricart (1972).

A identificação de feições geomorfológicas associadas com deslizamentos pode ser realizada em duas etapas, a primeira com um enfoque fisiográfico, onde é feito a delimitação das feições com base em um conjunto de observações fotointerpretativas e de campo, e a segunda, onde faz-se um estudo mais detalhado, utilizando parâmetros de análise do terreno, com base em medidas representativas da topografia e geometria das feições (declividade, amplitude, extensões, etc.) (BORGES, 2006).

A primeira avaliação pode ser dita global, a medida que envolve a análise das características topográficas da região, forma da superfície, drenagens, depressões locais e distinção da vegetação. Em geral, a instabilidade está associada a áreas de solos profundos, águas subterrâneas rasas, superfície relativamente íngreme, e encosta côncava em lugar de convexas. (WALKER 1987).

\subsection{PROCESSOS EROSIVOS}

Os processos de modelagem do terreno ocorrem constantemente na superfície da Terra, seja por meio do transporte de sedimentos, deposição nas partes mais baixas ou pelo soerguimento de terras em escala continental. São mudanças que variam em escala, volume e velocidade, podendo nem sempre serem notadas, ou ocorrerem de forma muito marcante provocando desastres de grandes dimensões (BERSSANI, 2012).

Os processos erosivos acontecem naturalmente, pela ação da água, ar, vento, gelo, organismos vivos e ação do homem, na superfície da terra. O seu desenvolvimento ao longo do tempo depende de fatores geológicos, como a presença de fraturas, é influenciado pela 
evolução físico-química e mineralógica do solo, e especialmente, tem a ação da chuva como deflagrante.

Devido aos riscos que a erosão apresenta hoje, tanto ambientais como socioeconômicos, é grande o número de estudos voltados ao seu diagnóstico e mitigação. Frente a isso, faz-se necessário que o estudo dos mecanismos de evolução das erosões tenha como base a análise de suas causas a partir de uma perspectiva ecológica/geológica/geomorfológica/geotécnica/social do fenômeno.

Desse modo, entende-se que os processos erosivos dependem também de fatores como o potencial de erosividade da chuva, as condições de infiltração e escoamento superficial e a declividade e comprimento do talude ou encosta e, ainda de fatores internos como gradiente crítico, desagregabilidade e erodibilidade do solo. (CAMAPUM, 2006)

Diversas são as formas e os meios pelos quais um processo erosivo pode ocorrer. A gênese de ravinas, voçorocas e movimentos de massa pode está ligada tanto ás alterações sofridas pelo solo em consequência de fluxos em meios saturados e não saturados em direção aos taludes, como por escoamentos superficiais e subsuperficiais, solapamentos, desmoronamentos e instabilidade de taludes. Sendo pois, que a grande parte do casos, é consequência de uma intervenção antrópica.

As características geomorfológicas de encosta tem, também, grande importância na ocorrência de processos erosivos. $\mathrm{O}$ aparecimento destes processos nas encostas denota algum desequilíbrio, comumente associado á participação do clima e de aspectos como a topografia, geologia, grau de intemperismo, natureza da cobertura vegetal e tipo de ocupação do solo. Logo, a intensidade das precipitações (volume) e sua frequência, associadas a forte declives, aos espessos mantos de intemperismo, e ao desmatamento, podem ser um campo fértil para erosões e movimentos de massa.

Tratando-se da magnitude dos processos erosivos, é fundamental a diferença que os solos têm entre si de ser mais ou menos suscetíveis ao destacamento e transporte das partículas (erodibilidade), aliado a habilidade da chuva em causar esse destacamento e transporte (erosividade). A quantificação desses dois fatores é importante na previsão da erosão e no planejamento do uso do solo. Entretanto, a erodibilidade dos solos tem sido o fator de maior interesse geotécnico. (LEAL \& ELLIOT, 1994 apud CAMAPUM, 2006). 
As consequências danosas dos processos erosivos sejam eles, ravinas, voçorocas ou movimentos de massa, podem ser assistidas em diversas partes do Brasil e do mundo, sendo potencialmente intensificadas com a ocupação do solo pela urbanização e acelerado incremento na atividade agropecuária. Por esse motivo a erosão é considerada um dos maiores riscos naturais, devido aos grandes danos econômicos e ambientais que provoca.

MARTINS (2005) elaborou para a área do Distrito Federal, um cadastro georreferenciado das áreas degradadas por processos erosivos, que resultou no cadastramento de 1252 feições, das quais 593 foram visitadas em campo em 9 das 19 regiões administrativas. Nessa pesquisa, Sobradinho apresentou o maior número de registros de todo o DF, e os limites que demarcaram essa R.A, considerados pela autora, incluem grande parte da Chapada da Contagem e, por conseguinte, o Ribeirão Contagem.

\subsubsection{Movimentos de Massa}

A dinâmica do relevo envolve os processos de encosta, e entre eles os movimentos de massa, que consistem no desprendimento e transporte de solo e/ou material rochoso ao longo de uma vertente. O material se desloca por gravidade devido a alguma condição de instabilidade, o qual ocorre de diferentes formas, dependendo dos mecanismos e características do material.

Muitos sistemas foram propostos para classificação de movimentos de massa (EPOCH, 1993; DIKAU et al., 1997; HUTCHINSON, 1988; IPT,1989; WOLLE, 1988), mas o sistema mais difundido é o de Varnes (1978). Tal sistema de classificação concorda com duas variantes: a primeira, descreve o tipo de material, e a segunda, descreve o tipo de mecanismo (VARNES, 1978). Os tipos de materiais considerados nas possibilidades de movimentos são rochas, solos, lama e detritos, e os tipos de mecanismos são: quedas (fall), tombamentos (topple), deslizamentos (slides), escoamentos (spreads) e corridas (flows). Combinando essas duas variantes tem-se:

- Quedas de Rochas (Rock fall) - São movimentos abruptos de massa de material geológico como rochas e pedregulhos que se desprendem do alto de encostas. O destacamento desses blocos ocorre ao longo de descontinuidades como fraturas, juntas e planos de estratificação e o movimento ocorre por 
queda livre. As quedas são fortemente influenciadas pela gravidade, intemperismo mecânico e pela presença de água intersticial.

- Tombamentos (Rock topple) - São quedas de blocos provocadas por falhamentos, e distinguem-se pela rotação frontal de um bloco ou vários blocos sobre um ponto central, por ação das forças de gravidade, forças exercidas por blocos de rocha adjacentes, ou fluidos em fendas.

- Deslizamentos (Debris slide) - Embora muitos tipos de movimentos de massa estejam incluídos no termo "deslizamento", a forma mais restrita do termo refere-se apenas a movimentos de massa onde há uma distingue-se uma linha de fraqueza que separa o material deslizado de material subjacente mais estável. Há dois tipos principais de deslizamentos:

a) Deslizamentos rotacionais: a superfície da ruptura se curva em forma côncava para cima e o movimento do deslizamento assemelha-se a uma rotação em torno de um eixo, e esse último é paralelo à superfície e transversal em todo deslizamento.

b) Deslizamentos translacionais: Neste, a massa deslizada se move ao longo da superfície de ruptura com pequena rotação ou inclinação para trás. O deslizamento de um bloco é um deslizamento translacional em que a massa movimentada é composta por um único bloco ou alguns blocos estritamente relacionados que se movem encosta a baixo como uma massa relativamente coesa.

- Escoamentos (Earth spread): Geralmente ocorrem em encostas muito suaves ou terrenos planos. O movimento é predominantemente lateral, acompanhado por cisalhamentos ou tensão de fraturas. O desprendimento é causado por liquefação, processo pelo qual sedimentos (geralmente areias e silte) saturados, soltos, são passados de um estado sólido para um estado liquefeito.

- Corrida (Debris-flow) - Há cinco categorias que se diferenciam entre si pelos meios que ocorrem:

a) Corrida de detritos (ou fluxo de detritos): é um tipo de movimento de massa rápido, onde há uma combinação de solo solto, rocha, matéria orgânica, ar e água mobilizados como uma lama que flui encosta abaixo vagarosa ou rapidamente. São compostos por $50 \%$ de finos. Geralmente são causados pelo intenso fluxo de água de superfície devido á 
precipitação ou degelo acelerado. As áreas de origem de fluxo de detritos estão frequentemente associadas com a incisão de canais íngremes, e a área de deposição desses fluxos é geralmente indicada pela presença de leques de detritos na saída de canais incisos. Encostas desnudadas por incêndios intensificam a suscetibilidade de pistas para fluxos de detritos

b) Avalanche de detritos: consiste em um fluxo de detritos muito rápido que passa para extremamente rápido.

c) Fluxo de terra: o material da encosta se liquefaz e corre formando uma bacia ou depressão. O fluxo é alongado e geralmente ocorre em materiais de textura fina, em condições saturadas e em relevos moderados. No entanto, fluxos de material granular não saturado também é possível.

d) Fluxo de lama: é um fluxo de terra que possui material úmido suficiente para fluir rapidamente, e que contém pelo menos $50 \%$ de areia-silte e partículas tamanho argila.

e) Rastejo: é um movimento imperceptível, constante e lento de solo ou rocha, na encosta. è causado por uma tensão de cisalhamento suficiente para produzir uma deformação permanente, mas pequena demais para produzir uma falha de cisalhamento. È subdividido em três. Sazonal: quando o movimento ocorre na profundidade em que o solo tem sua umidade e temperatura afetada por mudanças sazonais. Contínuo: ocorre onde a tensão cisalhante excede continuamente a resistência do material. Progressivo: ocorre onde as encostas estão atingindo o ponto de falha como em outros tipos de movimento de massa.

Ressalta-se que há, porém, uma limitação quanto aos tipos de material. Embora os mecanismos propostos ocorram de maneira quase universal, há diversas outras classes de material que não sejam solo, detritos e rocha, e isso afeta a forma das rupturas e seus comportamentos. Bressani et al. (2012) ressalta a importância dos tipos de materiais em ambientes tropicais, e no Sul/Sudeste do Brasil em especial, pois há diversos tipos de estratos rochosos com grande variação mineralógica e estrutural, os quais podem ter papeis decisivos nos mecanismos de ruptura. Um exemplo são os solos saprolíticos, que variam de comportamento em função da rocha de origem. Podem comportar-se como argila frente ao 
cisalhamento em caso de terem grumos tamanho areia, reduzindo sua resistência para valores de resistência residual (RIGO, 2000).

A principal causa dos escorregamentos no Brasil é a água, que pode atuar como agente preparatório e deflagrador dos escorregamentos (FUTAI et al., 2012). Os solos espessos são decorrentes do clima topical e seus elevados índices pluviométricos. Em condição saturada ou não saturada, a água é quem comanda os processos de instabilização desses solos. Por sua vez, a topografia da superfície e as características do perfil de subsolo é que determinarão a forma e a geometria de um escorregamento.

Em solos não saturados, a queda de sucção reduz a resistência e pode tornar os solos mais instáveis. Terzaghi (1950) apud Futai et al. (2012) identificou com clareza, três causas de escorregamento: interna externa e intermediária. Internamente, com a subida do nível freático da encosta, há diminuição ou eliminação da coesão entre as partículas, o que reduz a resistência do solo, mesmo que, visivelmente, mantenha o aspecto normal. A resistência dos solos da encosta também pode ficar comprometida em casos de infiltração por água da chuva, ou quebra de tubulações. A ruptura ocorre quando os parâmetros de resistência não são suficientes para manter a estabilidade da encosta, diante de uma frente de umedecimento que atinja uma profundidade crítica.

Os escorregamentos também ocorrem no contato solo-rocha. Segundo Vargas (1999), um nível freático pode ser formado no contato de rochas impermeáveis ou mesmo permeáveis, e a elevação desse nível pode causar o escorregamento. Os desastres naturais podem estar associados a vários tipos de deslizamentos e por isso os mecanismos relacionados não podem ser generalizados. Futai et al. (2012) evidencia que em condições especiais a infiltração é responsável por alguns escorregamentos e fontes de materiais que geram as corridas de lama ou mesmo os fluxos de detritos.

\subsection{RESISTÊNCIA DOS SOLOS}

A ruptura dos solos é quase sempre um fenômeno de cisalhamento. Por exemplo, o escorregamento de um talude. Segundo Pinto (2000), a resistência ao cisalhamento de um solo pode ser definida como a máxima tensão de cisalhamento que o solo pode suportar sem sofrer ruptura, ou a tensão de cisalhamento do solo no plano em que a ruptura estiver ocorrendo. 
Para tanto, é preciso compreender o mecanismo de deslizamento entre as partículas do solo, analisando principalmente os fenômenos de atrito e de coesão.

Considera-se um corpo sobre uma superfície plana horizontal sob efeito de uma força vertical $\mathrm{N}$ transmitida pelo corpo, e uma força horizontal $\mathrm{T}$ necessária para fazer o corpo deslizar. Existe, neste caso, uma proporcionalidade entre a força tangencial e a força normal, sendo que a força tangencial deve ser superior ao coeficiente de atrito gerado pela força normal, para que esse corpo deslize.

O angulo de atrito, por sua vez, será o angulo máximo que a força transmitida pelo corpo à superfície pode fazer com a normal ao plano de contato sem que ocorra deslizamento (PINTO, 2000).

O fenômeno de atrito no solo se faz envolvendo um grande número de grãos, que podem deslizar entre si ou rolarem uns sobre os outros. As forças transmitidas nos contatos entre os grãos, caso estes sejam de areia, são suficientemente grandes para expulsar a água da superfície, fazendo com que os contatos ocorram entre os dois minerais. Já nas argilas, por conta do grande número de partículas, a força transmitida num contato é extremamente reduzida; logo, não é suficiente para remover as moléculas de água envolvidas em suas partículas (quimicamente adsorvidas). Portanto, seriam estas moléculas de água, responsáveis pela transmissão das forças (PINTO, 2000).

O fenômeno da coesão ocorre devido a atração química entre as partículas. E isso pode causar, independente da tensão normal, uma resistência aos solos. Para Pinto (2000), essa seria a coesão real, como se uma cola tivesse sido aplicada entre dois corpos. Comparada à resistência causada pelo atrito entre os grãos (ex: solos sedimentares), a coesão é muito pequena. Mas vê-se um significativo valor de coesão entre os solos evoluídos pedologicamente, e/ou naturalmente cimentados por agentes diversos.

Os estados de tensão atuantes num solo variam a depender da quantidade de água contida nesse solo. A resistência ao cisalhamento está diretamente ligada a isso, pois vem a sofrer alterações diante dos processos de infiltração e umedecimento dos solos.

"A mecânica de solos saturados tem ênfase no comportamento de areias, siltes e argilas naturais, geralmente submetidas as poropressões de água positivas; já a mecânica de solos não saturados busca a compreensão do comportamento de solos naturais "dessecados", sejam eles transportados ou residuais" (GITIRANA JR., 2006). As poropressões negativas, 
características de solos não saturados, afetam os estados de tensões do solo e as interações físico-químicas e por isso os solos passam a ter um comportamento mais complexo, tanto macroscopicamente quanto na escala das partículas.

Segundo Gan (1986 apud Gitirana, 2012), a taxa de ganho de resistência ao cisalhamento parece seguir o valor do ângulo de atrito efetivo para valores de sucção baixos e, posteriormente, quando a sucção é aumentada, parece seguir taxas de ganho cada vez menores. Este comportamento reflete o estado de tensões nos micro e macroporos. Nos macroporos começam a ocorrer modificações no estado de tensões, depois passa para um estágio com ação predominante nos microporos, de forças coesivas; e numa terceira fase, essa energia na escala micro pode diminuir à medida que os contatos interpartículas saturarem o seu efeito.

Este comportamento não linear, com perda de resistência para altas sucções, também foi observado no DF, para a chamada argila porosa colapsável de Brasília, por SANTOS et al. (2006). Estes solos apresentam uma descontinuidade na curva granulométrica, no intervalo do peneiramento fino (CAMAPUM et al., 1996), que pode ser explicada pelo tipo de argilomineral, bem como pelas ligações entre os agregados, compostas por concreções oriundas do processo de cimentação ocasionado por óxidos e hidróxidos de ferro e alumínio ou pontes de argila. Esses solos tornam-se muito coesivos, formando um arranjo estrutural composto de agregados que funcionam em dois domínios: o dos microporos e o dos macroporos.

.Para analisar os problemas de estabilidade do solo é preciso compreender a natureza da resistência ao cisalhamento, que estão relacionados à capacidade de carga dos materiais, à estabilidade de taludes e pressão lateral em estruturas de contenção de terra.

As forças podem ser classificadas como compressivas ou trativas, dependendo das distorções de um corpo ou objeto. A força é considerada compressiva se as partes de um plano tendem a se aproximar segundo a direção da força aplicada, caso ocorra o contrário, a força é distensiva.

Para melhor entender a resistência ao cisalhamento, faz-se necessário o entendimento da atuação dessas duas forças, como explica Fiori (2001):

\footnotetext{
"As forças atuantes em um plano podem ter qualquer direção relativamente ao plano. Se uma força atua perpendicularmente ao plano, é dita como força normal, e se atua paralelamente ao
} 
plano, é chamada força cisalhante ou de cisalhamento. Geralmente as forças aplicadas não são direcionadas nem paralelamente nem perpendicularmente ao plano que se pretende analisar e, nesse caso devem ser decompostas em suas componentes normal e de cisalhamento designadas de (Fn) e (Fs) respectivamente. A componente normal pode ser classificada como compressiva ou trativa sendo comumente denominada de força cortante, por ser responsável pela ruptura ou corte dos materiais" (FIORI, 2001).

Para compreender melhor: tensão normal compressiva tende a inibir um movimento ao longo de um plano; a tensão normal distensiva tende a separar os blocos de rocha ao longo de um plano, enquanto a tensão cisalhante tende a promover o movimento diferencial dos blocos ao longo de um plano.

Critérios de ruptura são formulações que refletem o comportamento dos solos até a ruptura. A teoria de Mohr é tida como o método mais prático de se descrever a resistência do solo. Essa teoria preceitua que o rompimento ocorre numa massa de solo, e não no plano onde a tensão cisalhante é máxima, mas no plano onde há uma combinação crítica entre a tensão normal e cisalhante (DUNN et al., 1980).

A teoria de resistência de ruptura de Mohr é usada para avaliar tanto problemas de mecânica dos solos como de estabilidade de encostas, capacidades de carga máxima e pressões laterais. Essa é uma das formas mais comuns de representar a resistência de um solo e que melhor retrata o seu comportamento (SILVA, 2009). O critério de Mohr é análogo ao de Coulomb, como mostra a (Figura 1), originando o critério de Mohr-Coulomb, normalmente usado na mecânica dos solos.

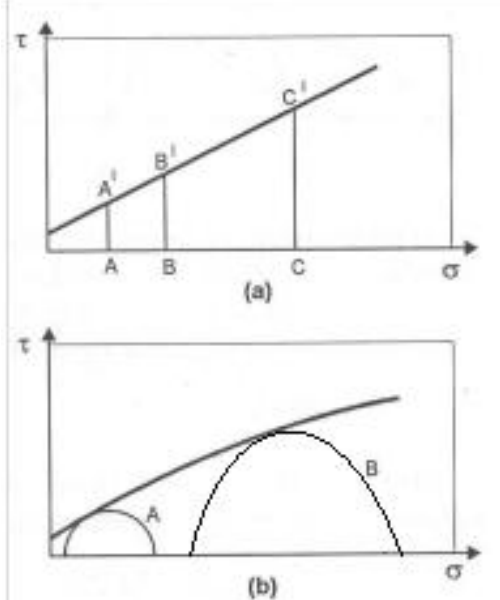

Figura 1 - Representação dos critérios de ruptura: (a) de Coulomb e (b) de Mohr.

Fonte: Modificado de PINTO (2000,) pela autora. 
Ao falar em resistência dos solos estar-se-á falando implicitamente de sua resistência ao cisalhamento, uma vez que as rupturas em um maciço de terra são devidas a deslocamentos relativos entre os grãos.

Esse tipo de análise envolve a determinação da tensão ao longo de um plano de tensões assumido, comparado à resistência ao cisalhamento do solo. Se a resistência do solo é maior que a tensão calculada, então a massa de solo está segura de romper, ao longo do plano de tensões assumido. Se a tensão for maior que a resistência, então ocorre o rompimento.

Alguns fatores são responsáveis por aumentar a resistência dos solos. A junção das moléculas na superfície em contato, em geral é regida por uma força de atrito, que segundo a Lei de Mohr gera uma resistência no plano de tensões. A coesão é uma parcela de resistência de um solo que existe independentemente de quaisquer tensões aplicadas, e se mantém mesmo que sejam removidas todas as tensões aplicadas ao solo. Diversas são as fontes que originam a coesão: atração química entre as partículas; cimentação entre partículas; tensões superficiais geradas por meniscos; tensões residuais da rocha de origem e atração iônica presentes na superfície dos argilominerais (SANTOS, 2013)

Lade (2010) demonstrou que para baixas tensões normais efetivas presentes em eventos de rupturas superficiais não é seguro utilizar o critério de ruptura de Coulomb para modelar a envoltória de resistência de tensões efetivas geralmente determinadas em altas tensões normais, pelo motivo de que não há coesão efetiva em solos não cimentados, de qualquer tipo.

O autor testou a magnitude da coesão efetiva de solos compactados representativos de solos das encostas do sul da Califórnia. A partir dos experimentos foi demonstrado que não há coesão efetiva em solos compactados, logo, esta (coesão efetiva) não pode ser considerada como uma propriedade que tem papel na manutenção da estabilidade das encostas.

O critério de ruptura de Coulomb com parâmetros de resistência $c^{\prime}$ e $\phi$ de testes convencionais superestimam a resistência ao cisalhamento disponível em baixas tensões normais, sendo este importante na análise de rupturas superficiais. Os resultados de testes de cisalhamento direto interpretados nos termos do critério de ruptura de Coulomb não são apropriados para avaliar a estabilidade superficial de encostas, pois o intervalo de tensões normais no campo não é usado em testes de laboratório. 
A resistência ao cisalhamento entre partículas de argila se manifesta pela resistência de atrito devido à tensão normal entre partículas. Sabe-se que os argilominerais possuem carga elétrica, e por isso é possível que haja um acréscimo de resistência ao cisalhamento quando a tensão normal for zero, e isso se deve à atração eletrostática e eletromagnética e também pelos limites inter-partículas (MITCHELL \& SOGA, 2005). 


\title{
3 ANÁLISE GEOMORFOLÓGICA E GEOTÉCNICA EM ENCOSTAS SUSCETÍVEIS A DESLIZAMENTOS ROTACIONAIS DE SOLOS NA BACIA DO RIBEIRÃO CONTAGEM - DF
}

\begin{abstract}
RESUMO
Os movimentos de massa são um dos fenômenos naturais que mais tem causado prejuízos, no mundo. O material transportado e depositado nas encostas em consequência de um movimento de massa, pode ser reconhecido por um número de características granulométricas, morfométricas e micromorfológicas, da encosta. A área de estudo localizase no Distrito Federal na Região Administrativa da Fercal, dentro da bacia hidrográfica do ribeirão Contagem. A pesquisa objetivou caracterizar os solos de três encostas a partir de dados geomorfológicos, e sedimentológicos, e, vincular esses resultados ao conjunto de tensões presentes nos materiais dessas vertentes, para conhecer suas condições de estabilidade e propensão a movimentos de massa. Foram traçadas três topossequências para investigação dos materiais presentes em encostas de morfologias distintas (concavidade fechada, concavidade aberta, e encosta convexo-retilínea), onde foi utilizado um trado manual. Foram coletadas 6 amostras indeformadas, em porções distintas das encostas. Através de testes de cisalhamento direto, foram aferidos coesão e ângulo de atrito e calculada a resistência dos materiais. Distinguem-se na área de estudo, três patamares de deposição bem delimitados que conferem comportamentos distintos para cada porção da encosta e fundo de vale. Obtiveramse altos valores de resistência ao cisalhamento para todas as porções das encostas, sendo que a convexo-retilínea apresentou a maior $(68,11 \mathrm{kPa})$. Os testes revelaram baixa coesão e angulo de atrito na área o vale. As curvas de ruptura apresentaram altas tensões cisalhantes suportadas pelos solos da encosta convexa, em detrimento das demais. A estabilidade dos materiais averiguada por esta pesquisa admite dizer que a ocorrência de fenômenos de deslizamento na bacia do ribeirão Contagem não estão predominantemente ligadas às características mecânicas dos materiais que as compõe. O que as análises geomorfológicas por sua vez nos intuem, é a existência pretérita da condição de eventos mais fortes que geraram as cicatrizes e deposições, observadas atualmente.
\end{abstract}




\begin{abstract}
Mass movements make up the hall of natural phenomena that have caused more damage worldwide. The material transported and deposited on the slopes as a result of mass movement can be recognized by a number of particle size, micromorphological and morphometric characteristics of the slope. The study area is located in the capital of Brazil, on Administrative Region of Fercal cover the Contagem hydrographic basin. The research aimed to characterize the soils This study aimed to characterize the soils of three slopes of a small area of the basin of the river Contagem, starting from geomorphological and sedimentological data, and link these results to the set of stress present in the materials of these strands, to meet its conditions of stability and propensity to mass movement. Three topossequences were drawn for investigation of the materials present in distinct morphologies slopes (closed concavity, open concavity and convex-rectilinear slope) where a manual soil auger was used. Were collected 6 undisturbed samples, in different portions of the slopes. Through direct shear tests were measured cohesion and friction angle and calculated the strength of materials. Were Distinguished in the study area, three well-defined deposition levels that provide different behaviors for each portion of the slope and valley bottom. Were obtained high shear strength values for all portions of the slopes, and the convex-rectilinear showed the highest $(68,11 \mathrm{kPa})$. The tests revealed low cohesion and friction angle in the valley area. The failure envelope curves showed high shear stress supported by the convex slope soils at the expense of others. The stability of the material investigated by this research admits say that the occurrence of sliding phenomena in the basin of the Countagem river are not predominantly related to the mechanical characteristics of the materials that compose it. What geomorphological analysis turn us intuit is the preterit existence of the strongest events condition that generated the scars and depositions currently observed.
\end{abstract}

PALAVRAS-CHAVE: geomorfologia de encostas, resistência ao cisalhamento, movimentos de massa.

KEY-WORDS: slope geomorphology, shear strength, mass movement.

\title{
INTRODUÇÃO
}

Os movimentos de massa ocupam o $7^{\circ}$ lugar dos desastres naturais que mais matam (Herath e Wang, 2009), contribuindo com cerca de 17\% das mortes por desastres naturais no mundo (Kjekstad e Highland, 2009). Desastres naturais são eventos prejudiciais que acontecem fora do controle das pessoas e são agravados, muitas vezes indiretamente, por intervenções humanas. Muitos impactos causados por movimentos de massa tem aumentado devido ao rápido crescimento urbano.

Os efeitos de deslizamentos tem afetado diversos aspectos da vida humana e do meio ambiente natural e muitas dificuldades surgem no sentido de fazer uma avaliação acurada desses eventos. Geralmente, movimentos de largos volumes de solo ou rocha vindos de altas 
altitudes para baixas altitudes ao longo de encostas, são um fator permanente de alterações topográficas da Terra.

Diversos estudos tem sido feitos sobre movimento de massa como: causas de movimentos de massa e seus principais efeitos; parâmetros respectivos a sensibilidade da encosta; desenvolvimento de sistemas de alerta, fornecimento de mapeamentos de deslizamentos e suscetibilidade para uso em programas de desenvolvimento urbano; medidas mitigadoras de prováveis deslizamentos; investigação de impactos e perdas e numerosos estudos de caso nos próprios cenários de rupturas.

A estabilidade de encostas está relacionado ao balanço entre os fatores que aumentam a tensão cisalhante e os parâmetros que fornecem resistência a massa de solo, contra o escorregamento. Assim, Terzaghi (1959) mostrou que a ocorrência de deslizamento depende da diferença entre mudanças internas de uma encosta, por exemplo, fatores que induzem a redução da resistência ao cisalhamento, e causas externas, as quais dão origem ao aumento da tensão cisalhante. Movimentos de massa são na sua maioria desencadeados por precipitação, atividade sísmica, intervenções humanas, vulcanismos, intemperismo, infiltrações e erosão fluvial. A partir daí, diferentes tipos de movimentos de massa podem ocorrer (baseado na classificação de Varnes (1978) por uma combinação de propriedades geológicas e geotécnicas dos materiais constituintes do solo da encosta, velocidade dos movimentos de massa e volume da área de deslizamento.

$\mathrm{O}$ aumento de intervenções humanas na natureza e no meio ambiente multiplicam os efeitos dos fatores que causam movimentos de massa. A mudança de padrões das áreas rurais, superpopulação e a urbanização descontrolada, principalmente em países menos desenvolvidos resultam em vulnerabilidade nas encostas e margens de rios, que pode não ser adequado para habitação ou outra tipo de interferência humana (BOMMER \& RODRIGUEZ, 2002).

Alimohammadlou et al. (2012) classificam as mudanças morfológicas e topográficas como um dos principais fatores, destes eventos deste eventos de deslizamentos. Em outras palavras, as mudanças na superfície da Terra será constantemente associada com o deslocamento de grandes volumes de solo, os quais frequentemente causam transformações na paisagem. No Distrito Federal, a ocorrência destes eventos e sua propensão é consideravelmente menor, comparado a outros estados. Isso se deve ao relevo, em geral mais aplainado. Mesmo com baixo número de desastres por deslizamentos, registradas no DF, é 
crescente o número de áreas consideradas suscetíveis, o que não anula as preocupações de ocorrência de um evento catastrófico e suas consequências para a população.

A bacia hidrográfica do ribeirão Contagem, onde está inserida a Região Administrativa da Fercal, ocupa uma região geomorfologicamente distinta do restante do DF, onde podem ser observadas encostas íngremes e ocupações irregulares (BRAGA, 2013). Esse cenário expressa uma situação potencial de risco, haja vista que 55\% das feições erosivas (movimentos de massa não foram incluídos) mapeadas na área encontram-se em áreas de alto potencial erosivo, segundo Santos (2013) , além de serem áreas de crescente número de habitações desordenadas. As encostas escolhidas para esse trabalho estão localizadas na Fazenda Buraco, área próxima a movimento de massa e limítrofe a área de expansão de ocupações irregulares de alta densidade. Nesse sentido, pretende-se caracterizar os solos dessas encostas para conhecer os aspectos geomorfológicos e geotécnicos que influenciam na estabilidade, destas.

\section{Área de estudo: Bacia do Ribeirão Contagem - Fazenda Buraco}

A bacia do Ribeirão Contagem possui $146 \mathrm{Km}^{2}$, onde coexistem grandes áreas de mineração de calcário, cascalheiras, ocupações irregulares, intervenção de estradas, focos potenciais de poluição, e grandes áreas de vegetação preservada, com elevada diversidade florística. Estudos já realizados na área da bacia explicitam que grandes volumes de perda laminar do solo são propiciados pelas altas declividades $\left(>35^{\circ}\right)$, fazendo com que, mais rapidamente, haja o recuo das vertentes (MARTINS et al., 2005). No compartimento onde essa atividade acontece são ativos os processos de erosão e deposição, resultando em altos índices de aprofundamento das drenagens que se desenvolveram.

A alta ocorrência de feições erosivas na bacia (BRAGA, 2013) ainda se integra a movimentos gravitacionais de solo (Figura1), que também são observados na área, ainda que em menor concentração, promovendo um aumento da vulnerabilidade da bacia, a esses movimentos. Segundo Santos (2013), 36\% da geometria do relevo é formada por áreas côncavas, $19 \%$ por retilíneas e $46 \%$ por formas convexas. As feições erosivas estão concentradas nas áreas côncavas (62\%), seguindo com $36 \%$ nas áreas convexas e 2\% em formas retilíneas (SANTOS, 2013). Esta distribuição provavelmente se dá pela concentração de fluxos superficiais e subsuperficiais em áreas convergentes o que contribui para ocorrência dos processos erosivos.

Na bacia do ribeirão Contagem podem ser observados diversos núcleos de ocupações irregulares em fundos de vale e encostas, sendo, portanto, uma área bem representativa de 
encostas em risco. Na figura 2 é visível o forte trabalhamento do rio e a presença de outros movimentos de massa, ao longo do canal fluvial que passa pela fazenda Buraco. A declividade ao longo do canal fluvial apresenta encostas superiores a $35^{\circ}$ em alguns pontos, principalmente em concavidades, e no geral varia de $10^{\circ}$ a $30^{\circ}$ (Figura 2).
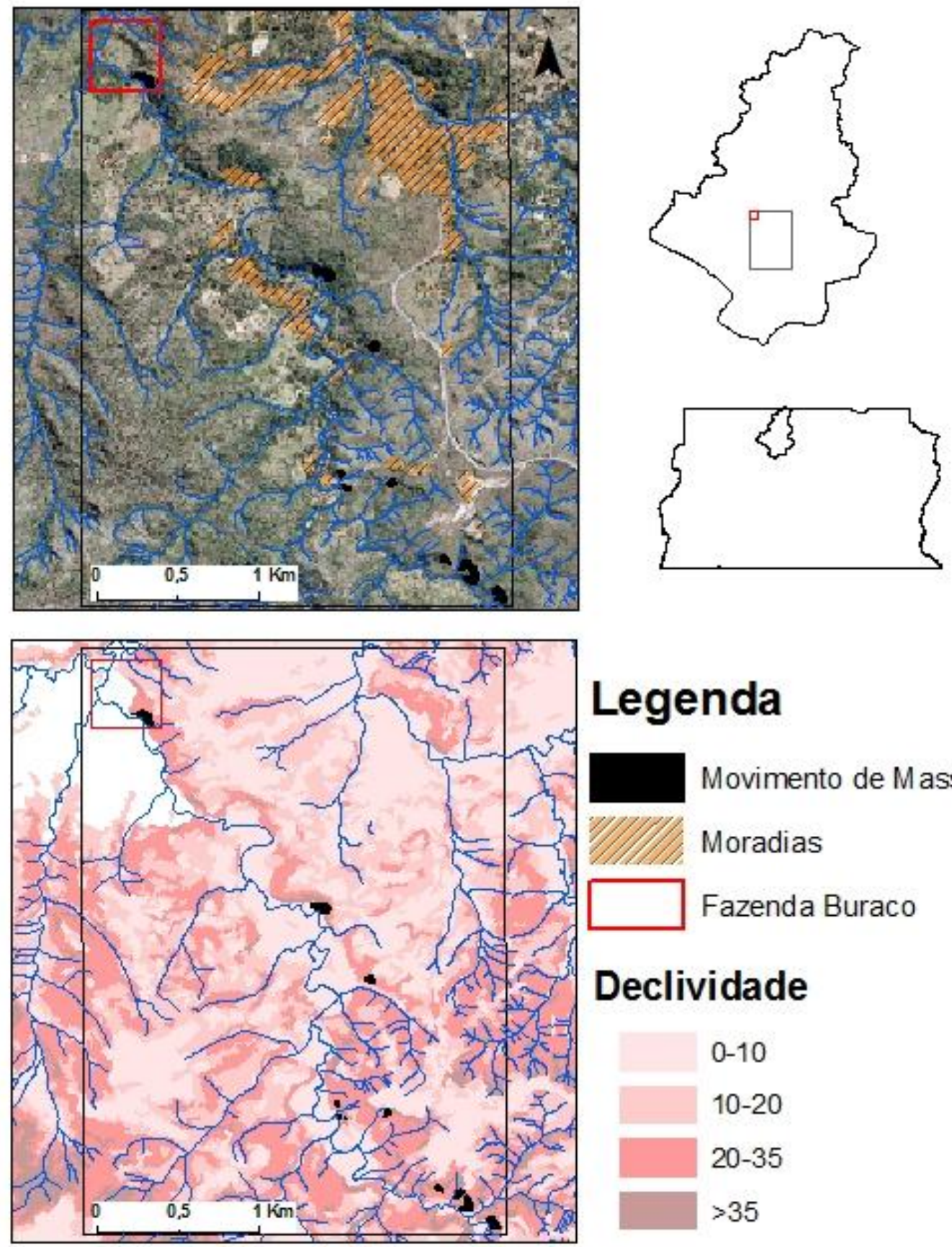

\section{Legenda}
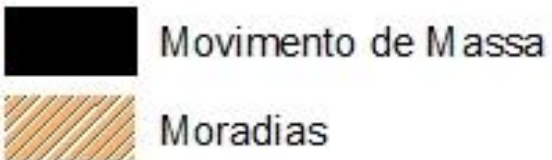

$\square$ Fazenda Buraco

\section{Declividade}

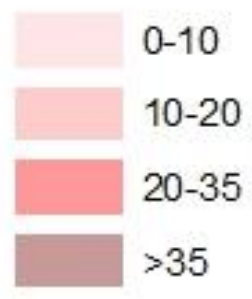

Figura 2 - Mapa da área e mapa de declividade do canal fluvial que passa pela fazenda Buraco

A fim de facilitar os estudos de solo foi escolhida área representativa da bacia, que possui encostas de diferentes formas e um deslizamento, em uma área de $0,186 \mathrm{~km}^{2}$ (Figura 2). 
A Fazenda Buraco (Figura 3) é uma propriedade que fica às margens do ribeirão Contagem, e foi escolhida para este estudo como uma amostra da bacia. A margem esquerda do córrego, na porção que passa pela fazenda é recoberta por uma mata degradada, e na margem direita uma área de pasto. Numa escala de 1:10.000 a área da fazenda Buraco está sob litologia de Psamo Pelito Carbonatada e Metassiltito Argilos (FREITAS-SILVA \& CAMPOS, 2013) e é recoberta por solos do tipo Cambissolo Háplico e Nitossolo Vermelho, de acordo com o mapeamento feito por Embrapa, 1978.

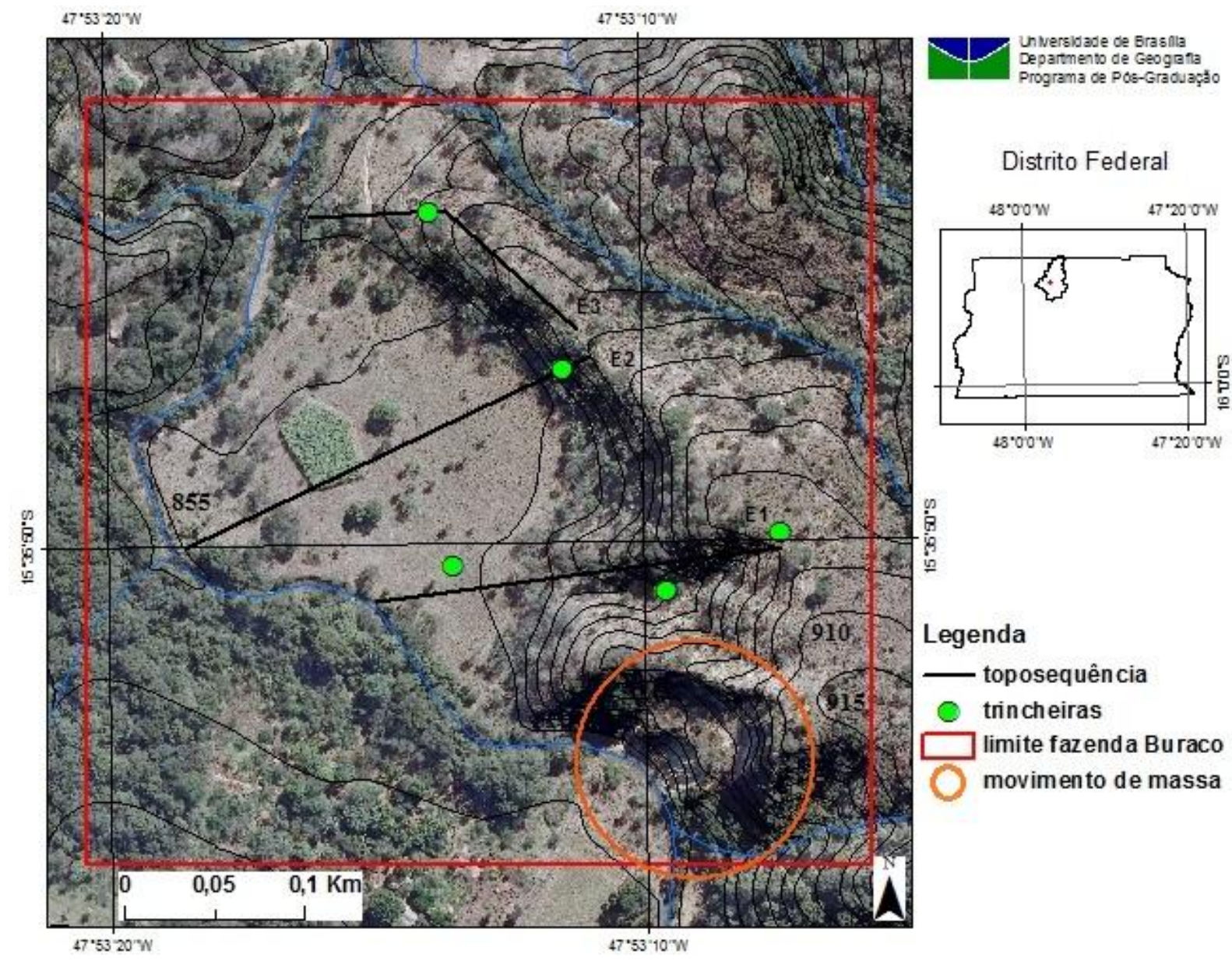

Figura 3: Mapa da área da fazenda Buraco.

A escolha dessa área se justifica principalmente pela presença de um movimento de massa rotacional (Erro! Fonte de referência não encontrada.), e sua representatividade em relação à dinâmica geomorfológica da bacia. 


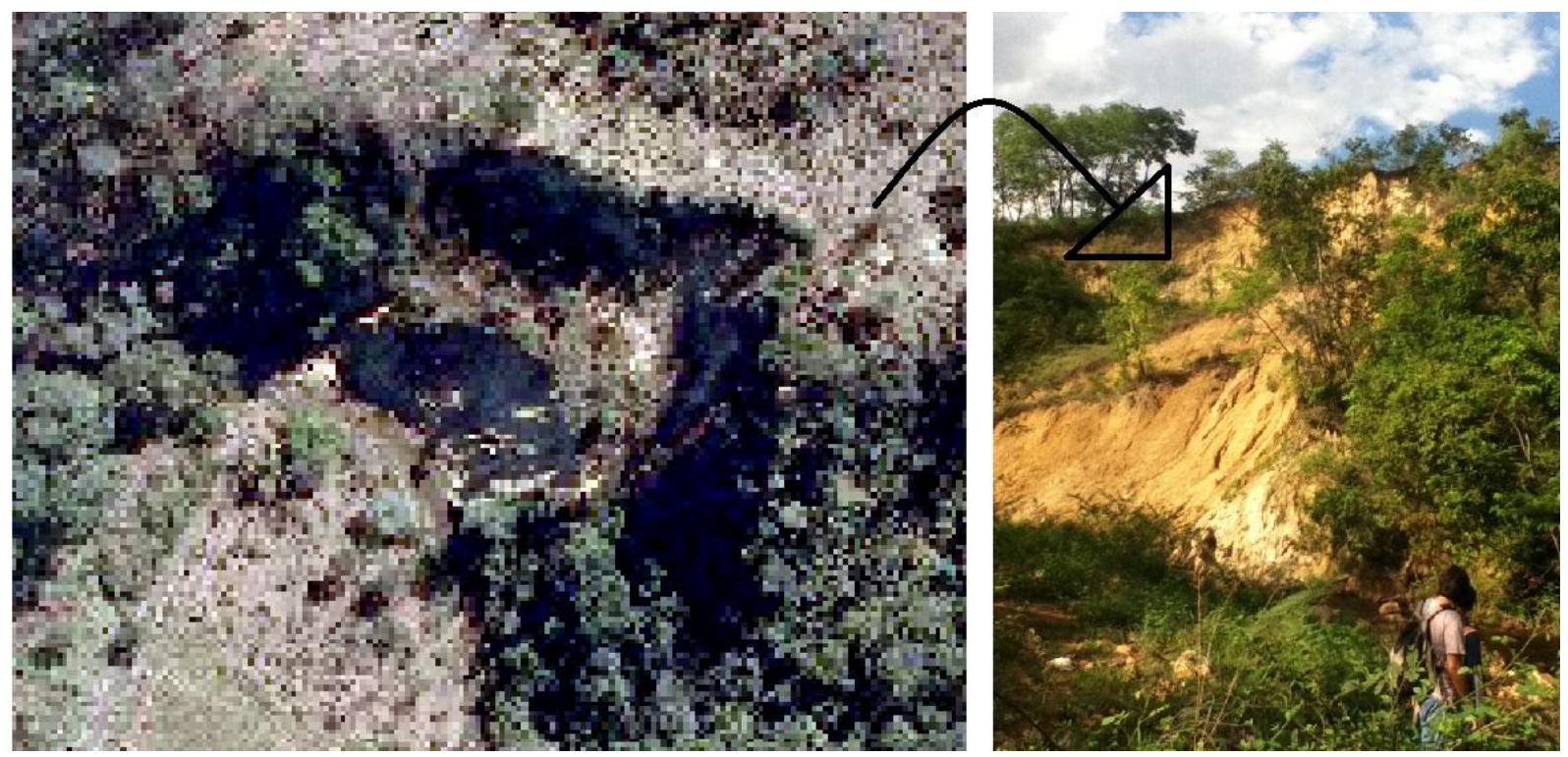

Figura 4 - Fotos do deslizamento rotacional na fazenda Buraco

Ademais, há naquela porção os três tipos de formas geométricas de encosta, representativas de diferentes processos de evolução do relevo e, portanto, distintos em sua capacidade de estar ou não sujeitos a movimentos de massa: concavidade aberta, concavidade fechada, convexidade e depósitos de encosta e fundo de vale.

\section{MATERIAIS E MÉTODOS}

\section{Critérios de escolha da área}

$\mathrm{Na}$ fazenda Buraco, ao lado do movimento de massa, foram escolhidas três encostas, sendo elas: uma concavidade aberta, uma concavidade fechada e uma convexidade, por sua vez representativas de processos geomorfológicos distintos. As mesmas possuem perfil transversal de 226, 290 e 320 metros, respectivamente. Utlizou-se aqui o método da toposequência, para se conhecer a disposição lateral dos solos ao longo das encostas estudada, assim como detectar os contatos solo/saprolito, ao longo do perfil vertical. A concavidade fechada possui uma bifurcação e é suspensa, nela as coletas foram feitas com espaçamento de 20 metros. Na concavidade aberta e na convexidade, o espaçamento foi de 30 metros. Essa metragem foi escolhida por permitir coletas em pelo menos três porções da encosta: topo, 
onde o material se encontra in situ, media encosta, para caracterização de um material translocado e baixa encosta, para caracterização de possível alúvio. O instrumento utilizado para a coleta das amostras de solo, foi um trado com caneco do tipo holandês de $11 / 2$ " de diâmetro, e caçamba de $10 \mathrm{~cm}$.

Foram coletados aproximadamente $600 \mathrm{~g}$ de solo em cada amostragem, os quais foram postos em sacos plástico, etiquetados e levados ao laboratório para análise granulométrica. A cor do solo foi aferida através da Carta Münsell, com o solo úmido, em campo.

\section{Perfis verticais e horizontais}

Em campo foram coletadas informações de nível do contato solo/rocha, e transições de cor do solo. Com essas informações, o perfil vertical foi desenhado e posteriormente plotado no perfil de cada encosta. O perfil vertical de cada ponto foi desenhado com o Inkscape, um software livre de edição de dados vetoriais, e os perfis das encostas foram desenhados em papel milimetrado com informações de altimetria, comprimento da encosta e altura da encosta, logo depois foram escaneados e vetorizados no software Illustrator CS4, da Adobe.

\section{Coleta e análise granulométrica}

Devido à investigação dos materiais subjacentes terem o foco na averiguação da profundidade, ou seja, contato solo/rocha, optou-se por fazer as amostragens de solo em quantidades de acordo com a profundidade que as tradagens alcançaram. Em caso de contrastes de solos entre amostras sequentes, o intervalo de coleta foi menor. As granulometria foi averiguada por pipetagem, pelo método de Ameida et al. (2012).

\section{Coleta de amostras indeformadas}

Findada a fase das tradagens, com o desenho do perfil lateral das encostas concluído, foram escolhidos pontos chave para a abertura das trincheiras. Foi aberta uma trincheira ao topo da concavidade fechada, com 1,70m de profundidade; na media encosta dessa mesma concavidade foi aberta uma trincheira com 1,60m de pronfundidade; na concavidade aberta ao topo, a trincheira foi a 1,50 de profundidade; ao meio dessa encosta, outra com $2 \mathrm{~m}$; na encosta convexo-retilínea foi aberta uma trincheira na média encosta, com $1 \mathrm{~m}$ de profundidade e outra na baixa encosta, próximo ao rio com $1 \mathrm{~m}$. Abriu-se a derradeira trincheira no vale, em área de deposição, com profundidade de 2,10 m. 


\section{Teste de resistência ao cisalhamento}

O ensaio de cisalhamento foi feito na ASTM D 3080-4 Standar Test Method for Direct Shear Test of Soils Under Consolidated Drained Conditions Os testes de cisalhamento foram feitos, utilizando-se uma prensa automática da marca Ele International , automatizada e calibrada, disponibilizada pelo Laboratório de Geotecnia da UnB. O ensaio foi realizado em uma célula de cisalhamento em seção quadrada. Utilizou-se um molde quadrado com dimensões de $11 \mathrm{~cm}$ de lado e $2 \mathrm{~cm}$ de espessura, utilizando a dita prensa. Os ensaio foram feitos em condições submergidas (24h), com limite para deslocamentos verticais de $5 \mathrm{~mm}$. Foram utilizadas tensões verticais de 50, 100 e 200kPa; a uma velocidade de deslocamento horizontal de $0,05 \mathrm{~mm} / \mathrm{min}$. A resistência de cada amostra foi calculada da seguinte forma:

$\tau=c+\sigma \operatorname{tg} \phi$ onde $c=$ coesão; $\sigma=$ tensão normal; $\operatorname{tg} \phi=$ tangente do ângulo de atrito. Foi feita uma correção no cálculo da área da caixa de cisalhamento, para que as resistências fossem calculadas de forma mais precisa, já que o movimento horizontal da caixa de cisalhamento, ao longo do ensaio, diminui a área de atuação da força vertical aplicada e por conseguinte os valores de tensão normal, no cálculo da resistência. Para isso, foi subtraído da área da caixa, o comprimento máximo do deslocamento horizontal de cada ensaio, obtendo-se um valor diferente de um dos lados da caixa,e assim a área foi recalculada para cada ensaio.

\section{RESULTADO E DISCUSSÕES}

As três encostas estudadas estão sob rochas e saprolito da mesma classificação, quais sejam: psamo pelito carbonatada e nitossolo vermelho, respectivamente (Erro! Fonte de referência não encontrada.). Localmente, porém é possível identificar em baixa encosta, neossolo flúvico, e em alta encosta, neossolo litólico. Encontram-se ambas sob vegetação degradada, caracterizada por gramíneas e árvores de médio e alto porte. Os perfis de topossequência foram traçados do topo de cada encosta à margem direita do córrego Sucurí (Figura 3).

A primeira encosta estudada (E1)(Erro! Fonte de referência não encontrada.) foi uma concavidade fechada, localizada ao lado de um movimento de massa rotacional. Essa concavidade é estreita principalmente na base, e possui uma bifurcação feita por uma parte residual da encosta, de morfologia convexa. Essa encosta tem declividade entre $20^{\circ}$ e $35^{\circ}$. As 
investigações dos materiais nessa encosta foram de Fevereiro a Junho de 2014. Foram feitos 14 pontos de perfil vertical traçados ao longo de $477 \mathrm{~m}$, com espaçamento de $20 \mathrm{~m}$.

A segunda encosta (E2) (Erro! Fonte de referência não encontrada.), trata-se de uma concavidade aberta, localizada exatamente ao lado da E1. Possui declividade entre $20^{\circ}$ e $35^{\circ}$ e uma pequena porção maior que $35^{\circ}$, onde a topossequência foi traçada. As tradagens foram feitas de Junho a Setembro, ao longo de $250 \mathrm{~m}$, com espaçamento de $30 \mathrm{~m}$. Foram feitos o total de 12 pontos de perfis verticais. A terceira encosta (E3) (Figura 3) tem morfologia convexo retilínea, formando um perfil lateral de $180 \mathrm{~m}$, onde foram caracterizados 5 pontos de perfil vertical. As tradagens se deram no mês de Setembro.

\section{Concavidade aberta - E1- descrição dos perfis verticais}

A (Figura 5) apresenta as principais características observadas em campo, por meio das tradagens. A escala apresentada corresponde à profundidade máxima a que se conseguiu averiguar os materiais. Nesta ilustração estão apresentados principalmente os limites de mudança de cor do solo e altura de fragmentos de rochas ou cascalhos, aferidos em campo. $\mathrm{O}$ contato entre solo e saprolito foi inferido nas observações de campo, e é apresentado aqui. No entanto, somente com as análises granulométricas foi possível atestar a partir de onde esta transição ocorre ( Figura 17). No intuito de fazer uma comparação, esses dois resultados serão apresentados.

\section{E1 - Concavidade fechada}

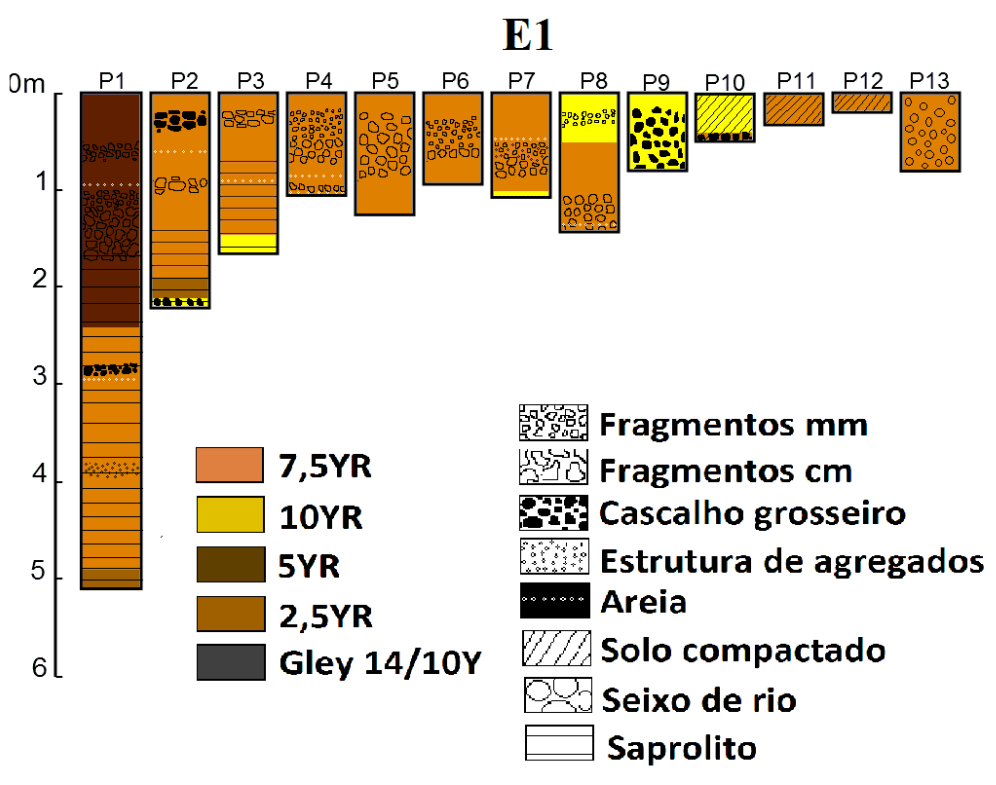

Figura 5 - Perfis verticais da E1 
No ponto 1 (topo da encosta) as tradagens alcançaram 5,1m de profundidade, com limite entre solo e saprolito acusado a 1,70m e alta variação da cor do solo ao longo do perfil, com fragmentos de couraça de tamanho crescente do topo até o início do saprolito. O ponto 2 e 3 situam-se em porção fortemente inclinada da alta encosta. Caracterizam-se principalmente pela presença de uma faixa de couraça. O ponto 4 e 5 situam-se na media encosta, em declive menos acentuado que os pontos anteriores, aqui há concentração de cascalho laterítico de diâmetro menor na superfície, que os pontos antecedentes.

O ponto 6 e 7 caracterizam a baixa encosta, e há presença de muitos cascalhos. $\mathrm{O}$ ponto 8 , já ao final da encosta, é marcado por uma morfologia quase plana. O ponto 9 é o primeiro ponto fora da encosta. Situa-se no início do vale, e apresenta seixos muito angulosos. Do ponto 10 em diante, todas as tradagens foram feitas na porção do vale (parte plana), sob área de pastagem.

Resultados granulométricos - Concavidade fechada( E1)

A Figura 6 apresenta as curvas granulométricas de todos os ponto coletados na E1 (concavidade fechada). As amostras analisadas distribuem-se do topo da encosta ao fundo do vale a diferentes profundidades. $\mathrm{O}$ gráfico mostra o acumulado das partículas a partir dos seus respectivos diâmetros, passados em conjunto de peneiras.

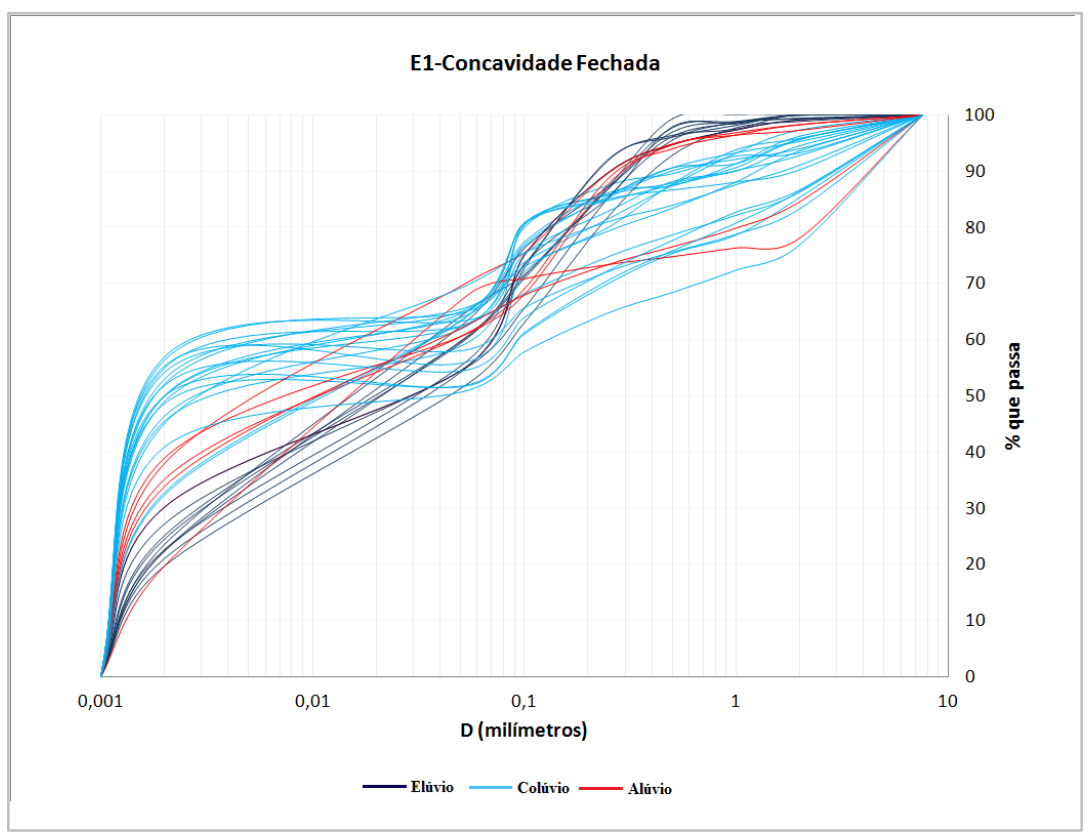

Figura 6 - Gráfico granulométrico da E1 
Por meio das análises granulométricas foi observado um comportamento padrão na curva das amostras mais profundas do P1, P2, P3, P4, P5. Este comportamento é caracterizado por nula ou mínima presença de areia grossa, percentual pouco considerável de areia média, e quantidades de partículas concentrada principalmente na fração silte e argila.

Ressalta-se que esse tipo de comportamento ocorre a partir de uma profundidade definida, sendo ela diferente para o topo e média encosta. Este padrão granulométrico caracteriza o que constatou-se, por meio das tradagens, ser o contato entre a rocha inconsolidada e o material pedogenisado, sendo este último, pouco espesso. Desta forma, o P1 apresenta este contato a partir de 1,5m da superfície, o P2 a partir de 1,15m; P3 e P4 a aprtir de 1,65 e P5 a partir de 90cm. O limite entre solo e saprolito (Figura 7) foi verificado em campo e validado com os resultados da curva granulométrica, com pouca variação entre um e outro.

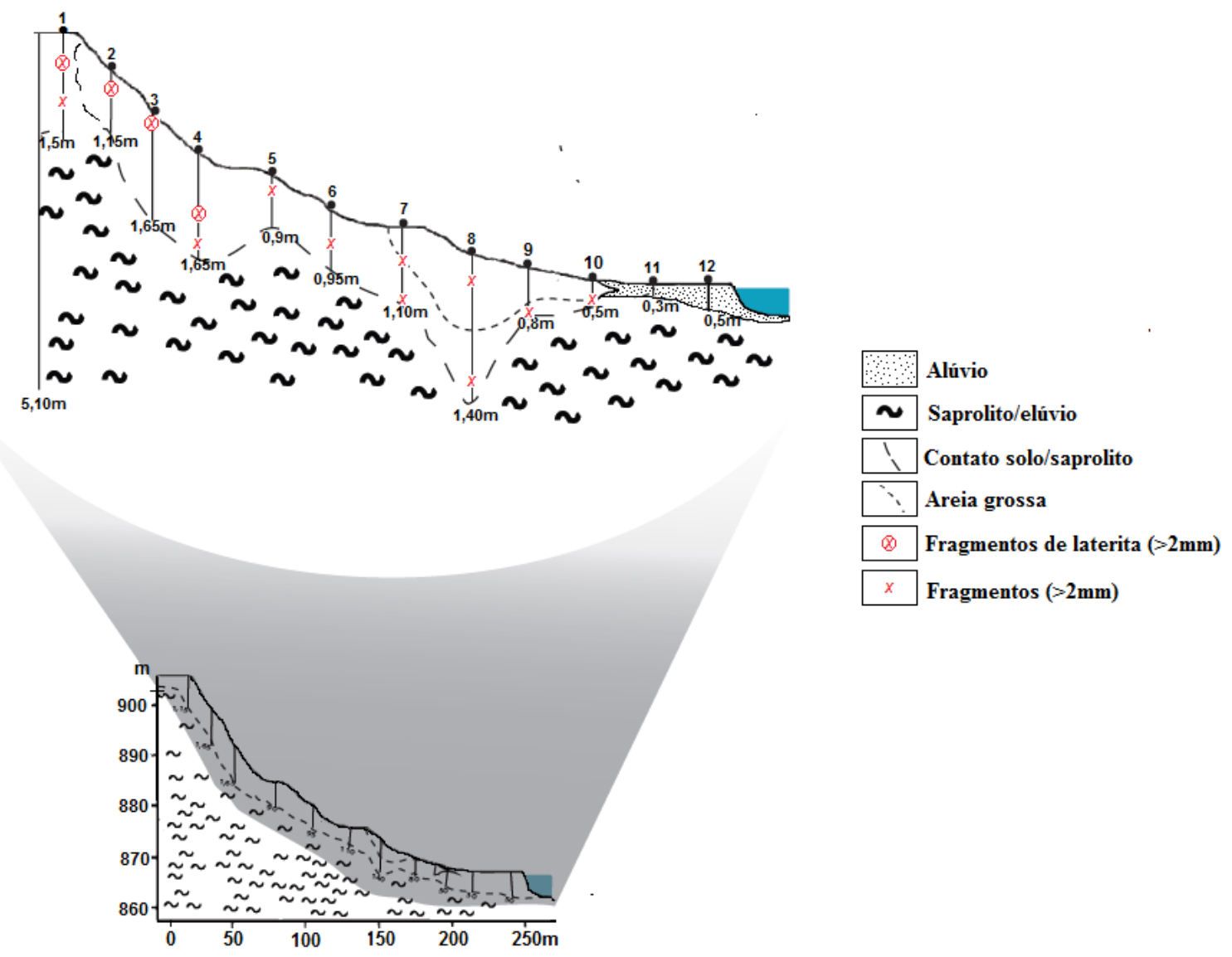

Figura 7 - Perfil lateral da concavidade fechada - E1 
As curvas granulométricas das amostras coletadas na camada superficial do P1 até o P10 se agruparam num mesmo comportamento, demonstrando semelhança no diâmetro das partículas. Estes pontos localizam-se do topo ao primeiro ponto do início do vale, a $20 \mathrm{~m}$ do fim da encosta, e seus materiais foram classificados como colúvio.

As curvas desses pontos citados, mostram solos em que $64 \%$ a $48 \%$ das partículas são inferiores a 0,1mm (Figura 6) e apresentam valores ligeiramente maiores de areia fina média e grossa, em relação aos encontrados no elúvio. Nestes pontos, foi encontrada uma heterogeneidade de materiais grosseiros como cascalhos lateríticos, grãos de quartzo e fragmentos de rocha intemperizada.

O comportamento diferenciado do P7A2 em relação aos outros materiais classificados como colúvio, se deve por esse ponto acumular um maior percentual de areia grossa, já que é a partir do P6 que partículas com esse diâmetro tomam expressividade na encosta. No entanto, a curva granulométrica desse ponto também não se aproximou do padrão do que veio a ser considerado alúvio, continuando na classificação dos colúvios, dada sua localização na encosta.

Uma comparação foi feita entre o P7A2 e o P8A1, sendo este último um ponto padrão, para que possa ser melhor visualizado tipos de comportamento distintos do mesmo material na E1 (Figura 8).

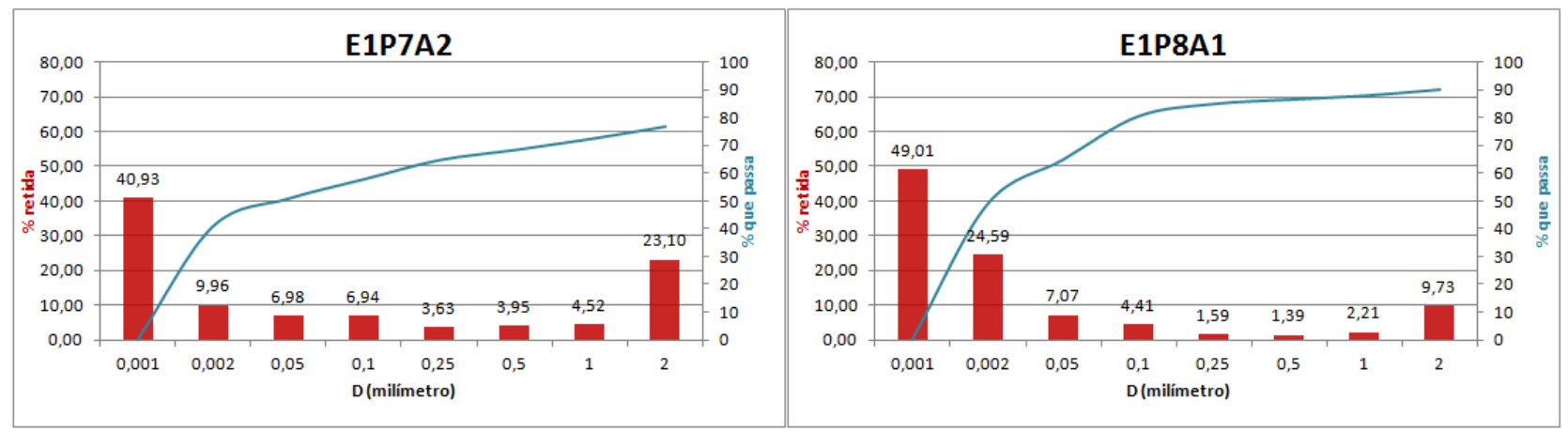

Figura 8 - Gráficos de comparação de comportamento do colúvio ( E1)

Análises morfoscópicas feitas por Caldeira (2015), na concavidade fechada, inteiram que as amostra retiradas no topo e meio da encosta possuem características de depósitos coluvionares devido à abundância de grãos irregulares, angulares e sub angulares com superfície rugosa. Características de depósitos aluvionares como abundância de grãos sub 
arredondados e arredondados indicando longo transporte sedimentar, foram osbervadas pela autora no P11 (Figura 9).

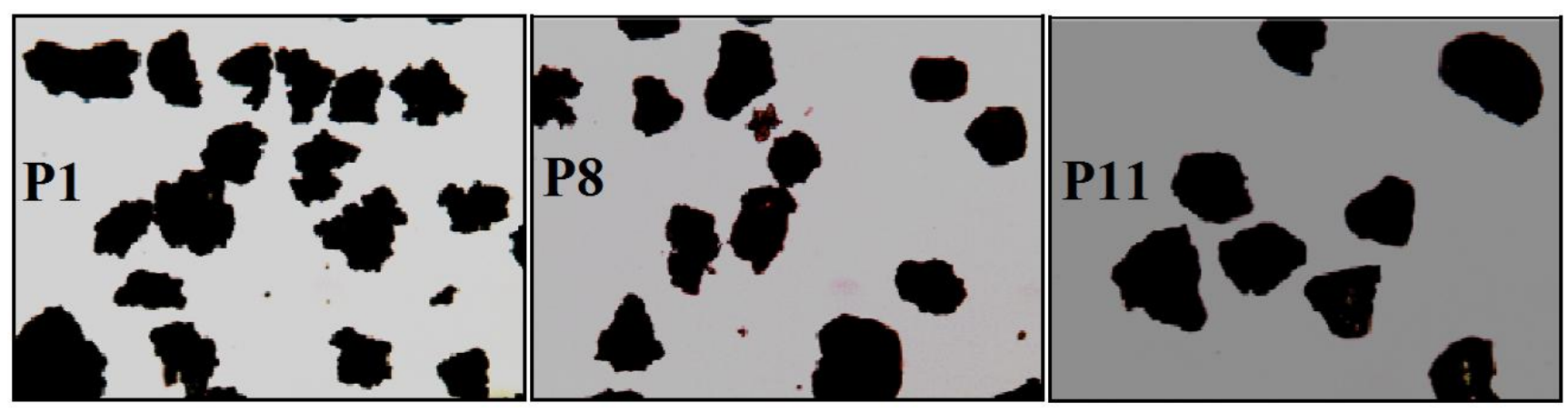

Figura 9 - Morfoscopia dos grãos de areia dos pontos P1, P8 e P11 da E1 (modificado de Caldeira,2015)

O ponto 10 localiza-se a $45 \mathrm{~m}$ da margem do córrego a uma profundidade de $40 \mathrm{~cm}$, quase metade (48\%) das partículas são silte e $21,9 \%$ são de areia grossa, motivo pelo qual esse ponto se diferencia dos demais que estão sob o vale. Essa areia pode ter sido depositada pelo rio em outro momento, já que nenhum ponto da encosta apresentou quantidade tão significativa de areia. Na Figura 10 são apresentadas as diferenças de comportamento entre dois pontos classificados como sendo material coluvionar: o P10A1, cujo comportamento foge do padrão observado para a maioria dos sedimentos considerados coluvionares, e o P13A1, que representa o comportamento da maioria dos pontos, com essa classificação.

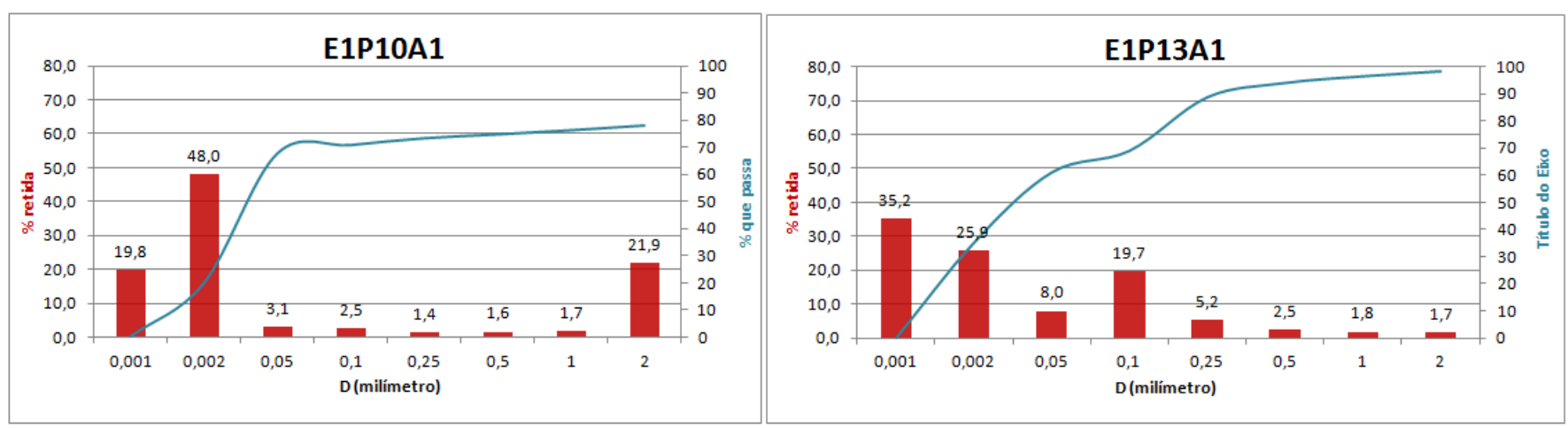

Figura 10 - Gráficos de comparação de comportamento de alúvio (E1)

Com os dados plotados no triangulo granulométrico ( 
Figura 11), confirmamos as classificações dos materiais, já que os solos com perfil saprolítico menos alterado se classificam como siltosos; os alúvios dessa topossequência classificaram-se como argilo-siltosos, e os colúvios em sua maioria, como argilosos.

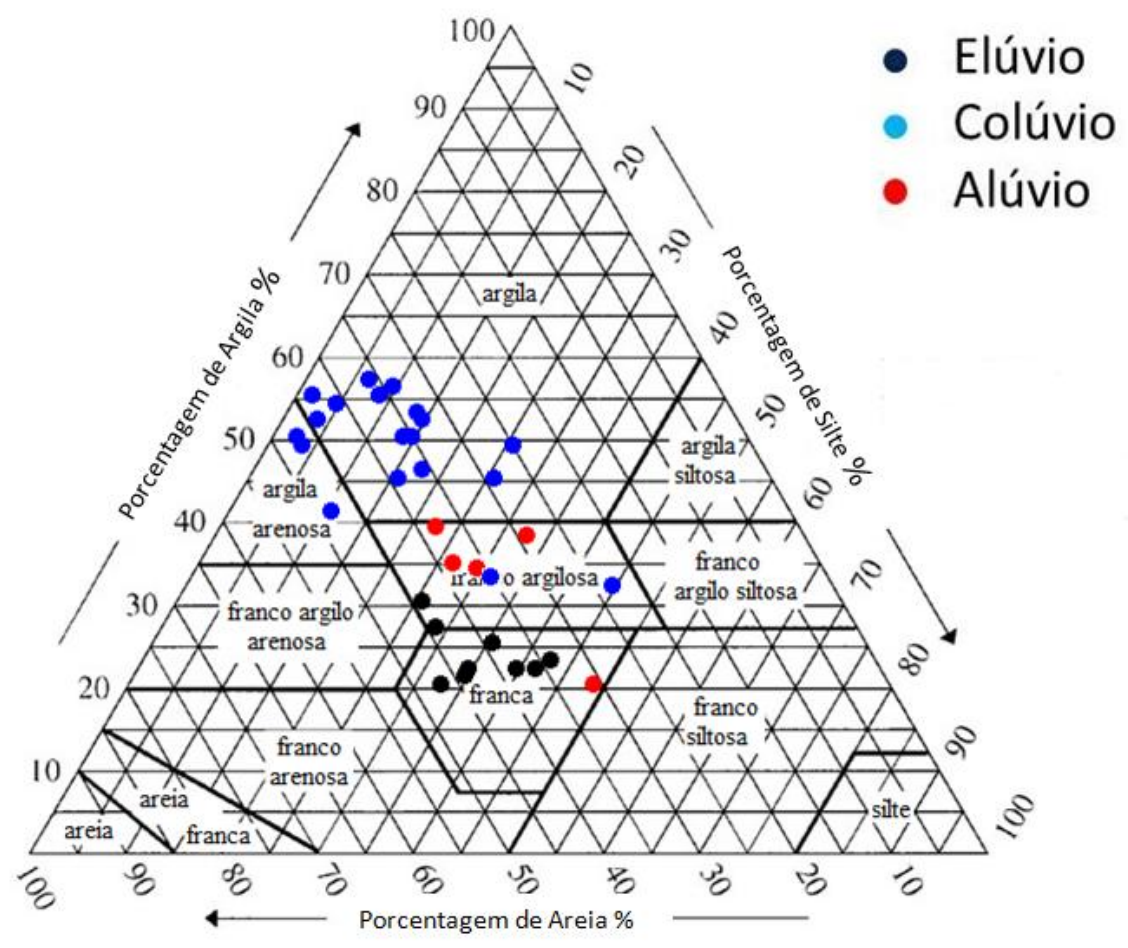

Figura 11 - Triangulo granulométrico E1

\section{Análises Geotécnicas - E1}

A seguir estão dispostos os gráficos das curvas de ruptura, plotados com as três tensões ensaiadas (

Figura 29), apresentando a reta de Mohr-Coulomb, cada uma com seu respectivo valor de ângulo de atrito e coesão.

Com os parâmetros $c$ e $\varphi$, de cada amostra, foi calculada a resistência ao cisalhamento para a porção médias da concavidade fechada 

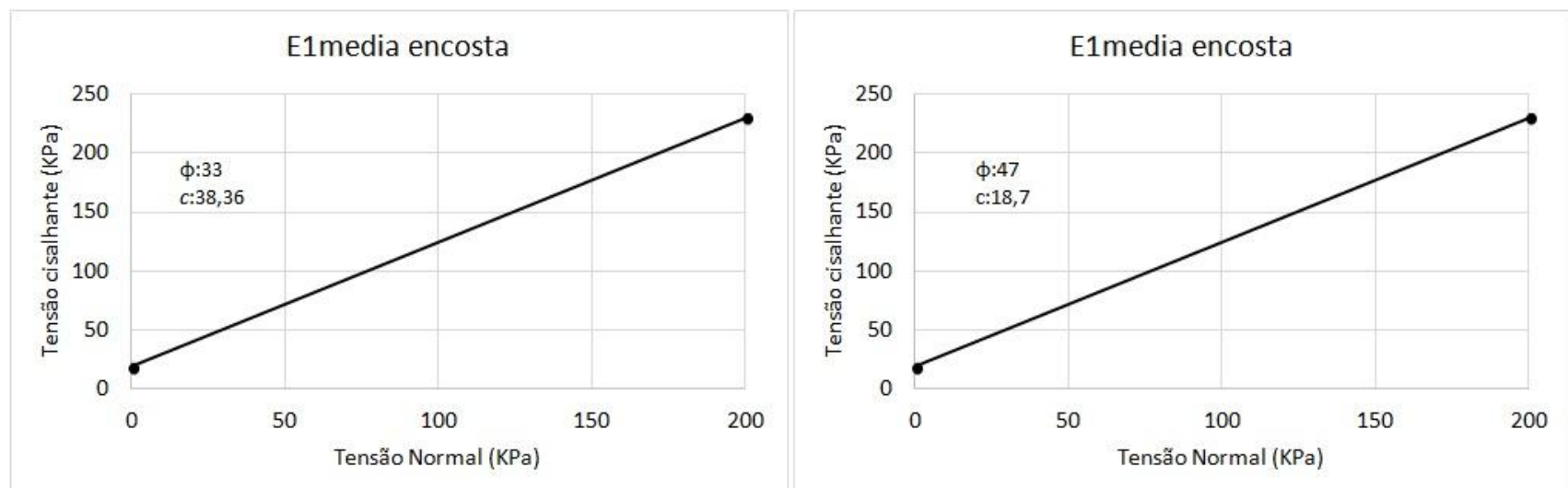

Figura 12 - Gráficos das curvas de ruptura da E1

As áreas de topos mostraram valores de atrito e coesão altos. A alta resistência dos materiais encontrados nos topo das encostas estudadas ( Figura 13) pode ser relacionado mais essencialmente com a atração química provocada pelas partículas de silte e argila, visto que estes solos estão em área plana, e tem sua granulometria concentradas nessas frações finas, como pôde ser observado anteriormente. Deve-se considerar também as tensões efetivas as quais estes solos possam estar, no campo, já que são pouco intemperizados, e, portanto podem apresentar maiores superfícies de contato grão a grão. Este motivo pode ser utilizado para explicar os altos valores de angulo de atrito e coesão dos solos medidos nas encostas analisadas

Resistência ao cisalhamento - E1

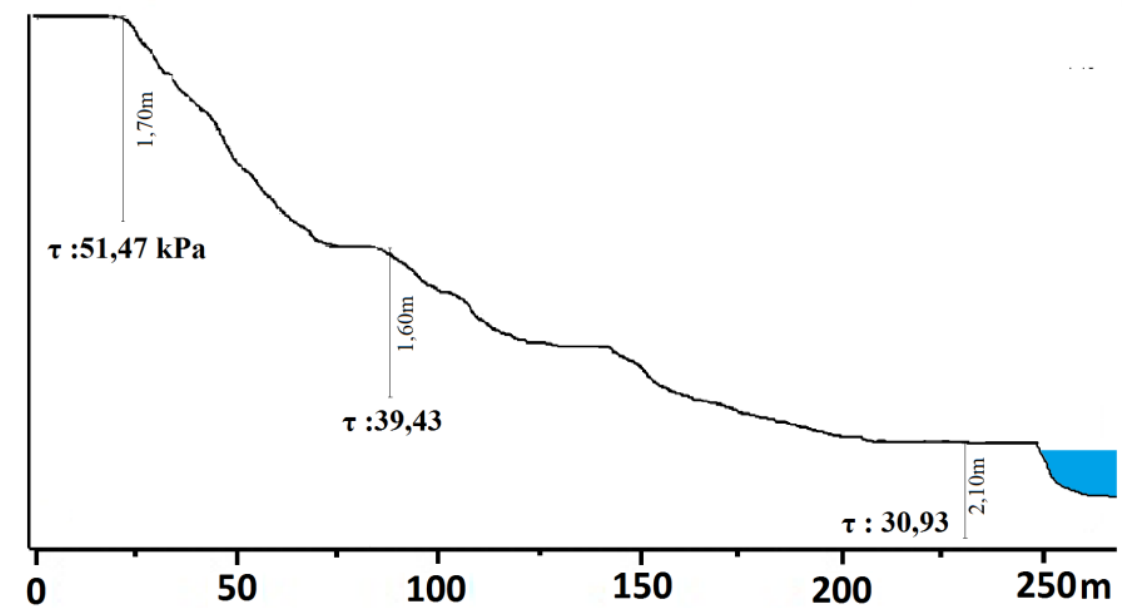

Figura 13- Resistência ao cisalhamento na porções da E1 e fundo de vale 
Fator de Segurança - E1

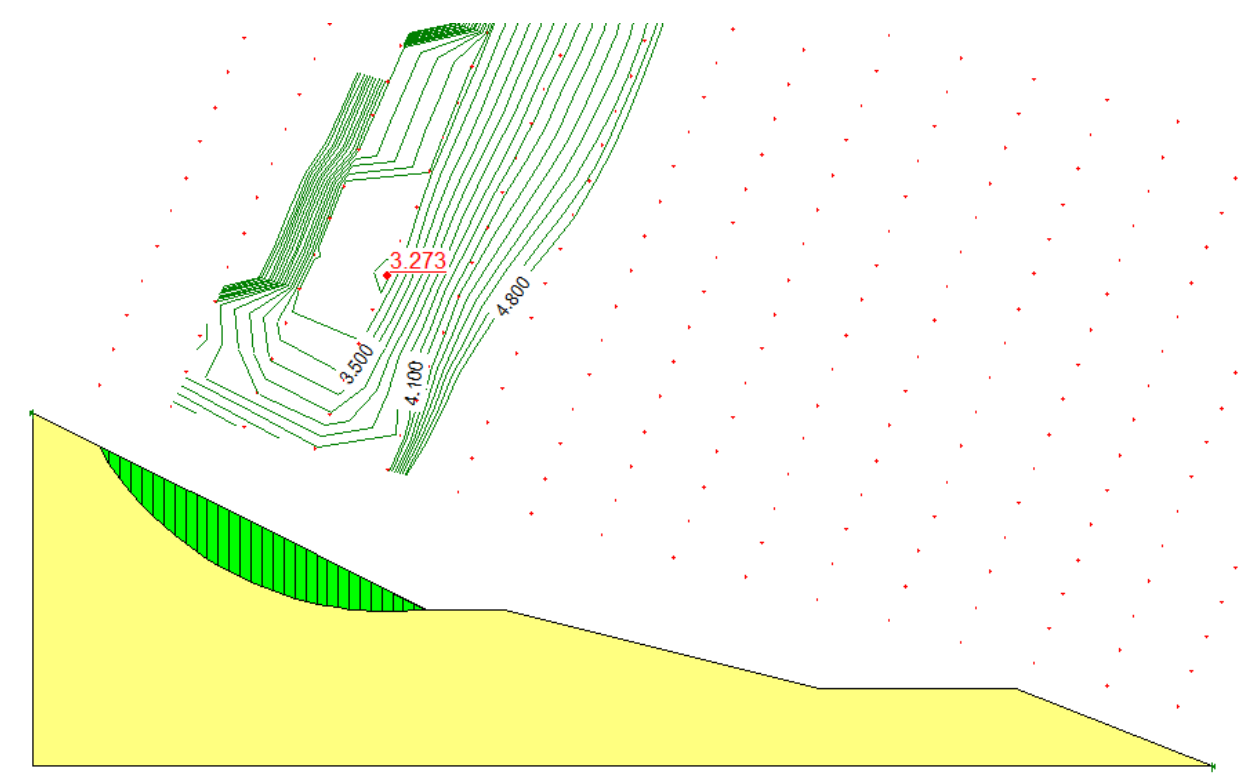

Figura 14 - Fator de segurança da E1 


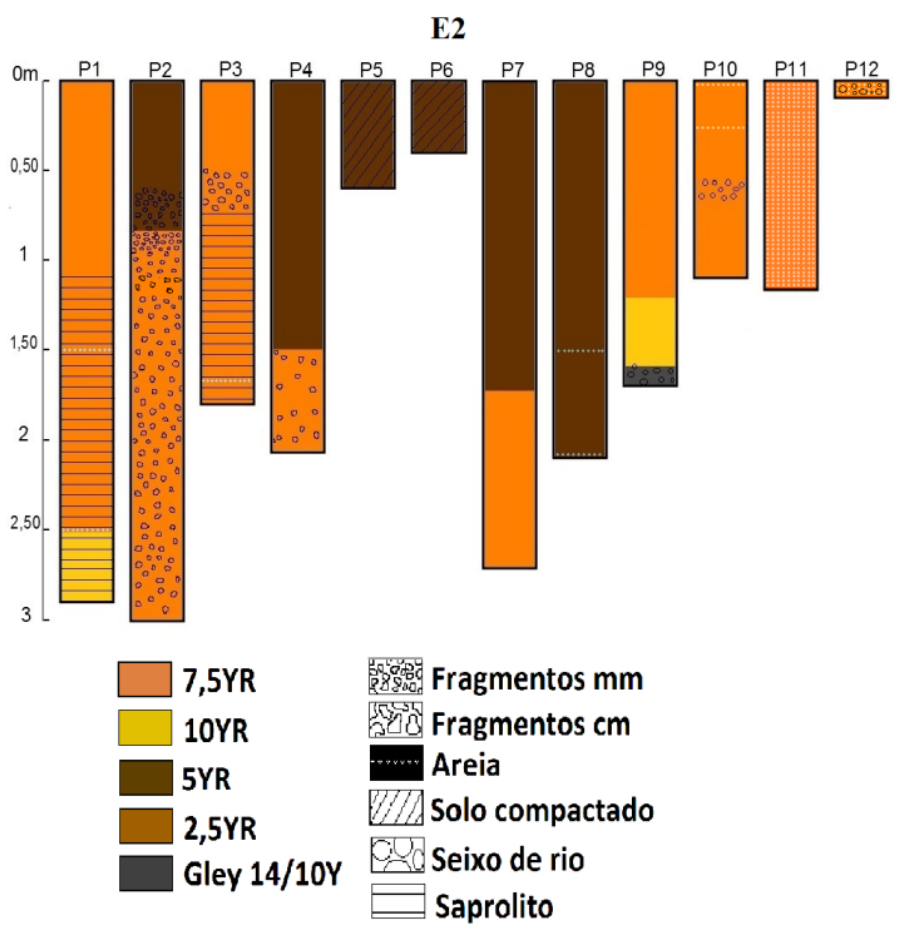

Figura 15 - Perfis verticais da E2

O ponto 1, 2 e 3 (topo) apresentam solos bem homogêneos de cor 7,5YR. O ponto 4 localiza-se em área plana, no fundo do vale, a $10 \mathrm{~m}$ do sopé da encosta e a $30 \mathrm{~m}$ do ponto 2. Neste ponto, há uma mudança abrupta na cor do solo. Os pontos 5, 6, 7, 8, 9, 10, 11 e 12 localizam-se no meio do vale, em área de pasto com solo muito compactado. Em todos os pontos há presença de fragmentos de quartzo e areia. O ponto 9 localiza-se próximo a um murundum, apresenta mosqueados a 1,25 m, uma transição para Gleissolo a 1,70 m e nessa mesma porção, seixos arredondados, evidenciando trabalhamento fluvial já ocorrido nessa área.

As curvas granulométricas geradas com os solos da concavidade aberta, demonstram visível padrão de comportamento entre materiais dessa encosta, que podem ser observados na Figura 16. 


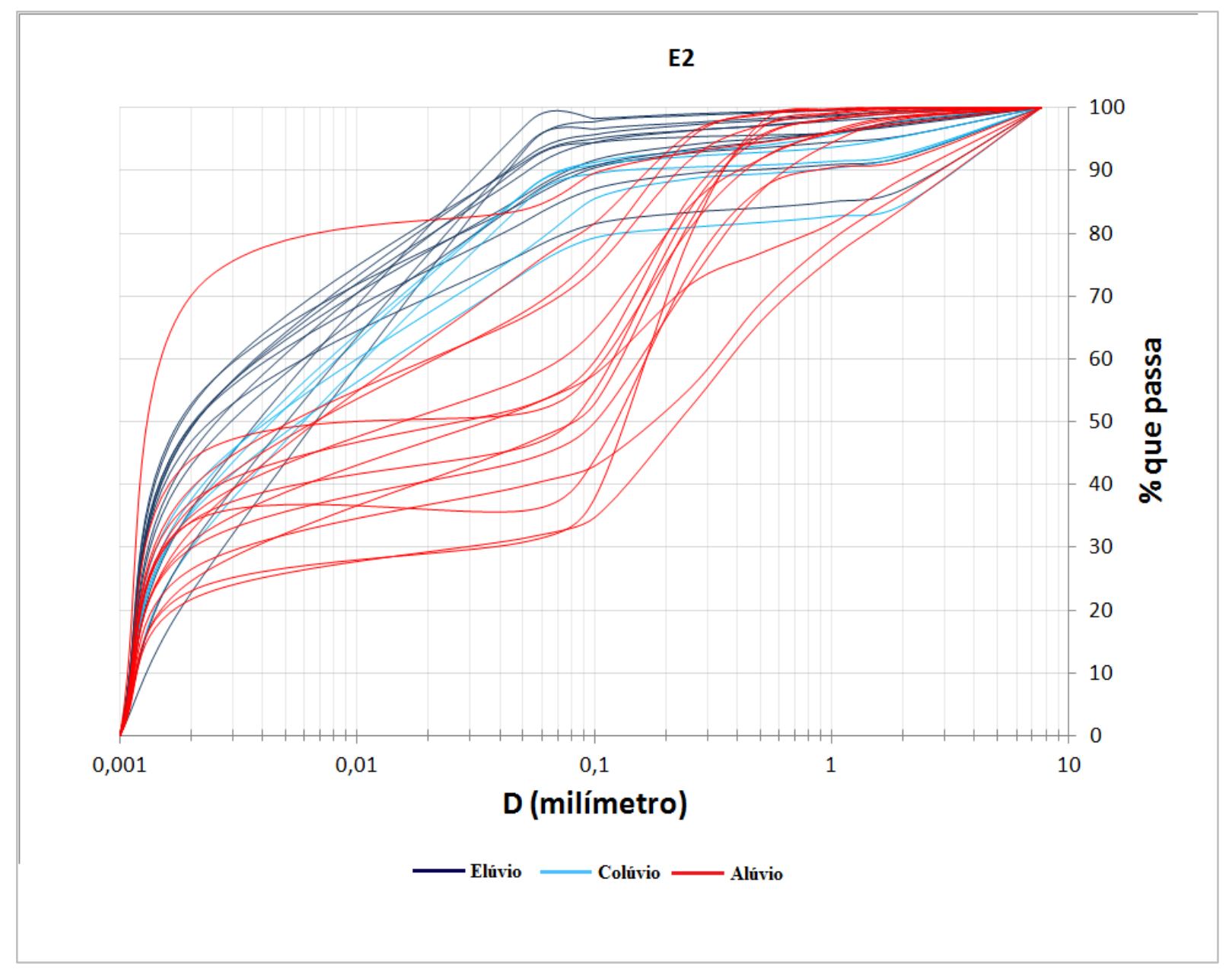

Figura 16 - Curvas granulométricas da E2

Em todos os 3 pontos que compõem do topo ao sopé da encosta foi observado o mesmo comportamento granulométrico nos solos, nas seguintes profundidades: $2,5 \mathrm{~m}$ no topo, $1 \mathrm{~m}$ na média encosta e 1,05 na baixa encosta. Estas profundidades sugerem o contato entre o solo e o material saprolítico, as quais foram usadas no desenho dos perfis.(Figura 17). Suas características principais são a presença de silte, que aumenta gradualmente de forma linear a partir do diâmetro $0,06 \mathrm{~mm}$. 


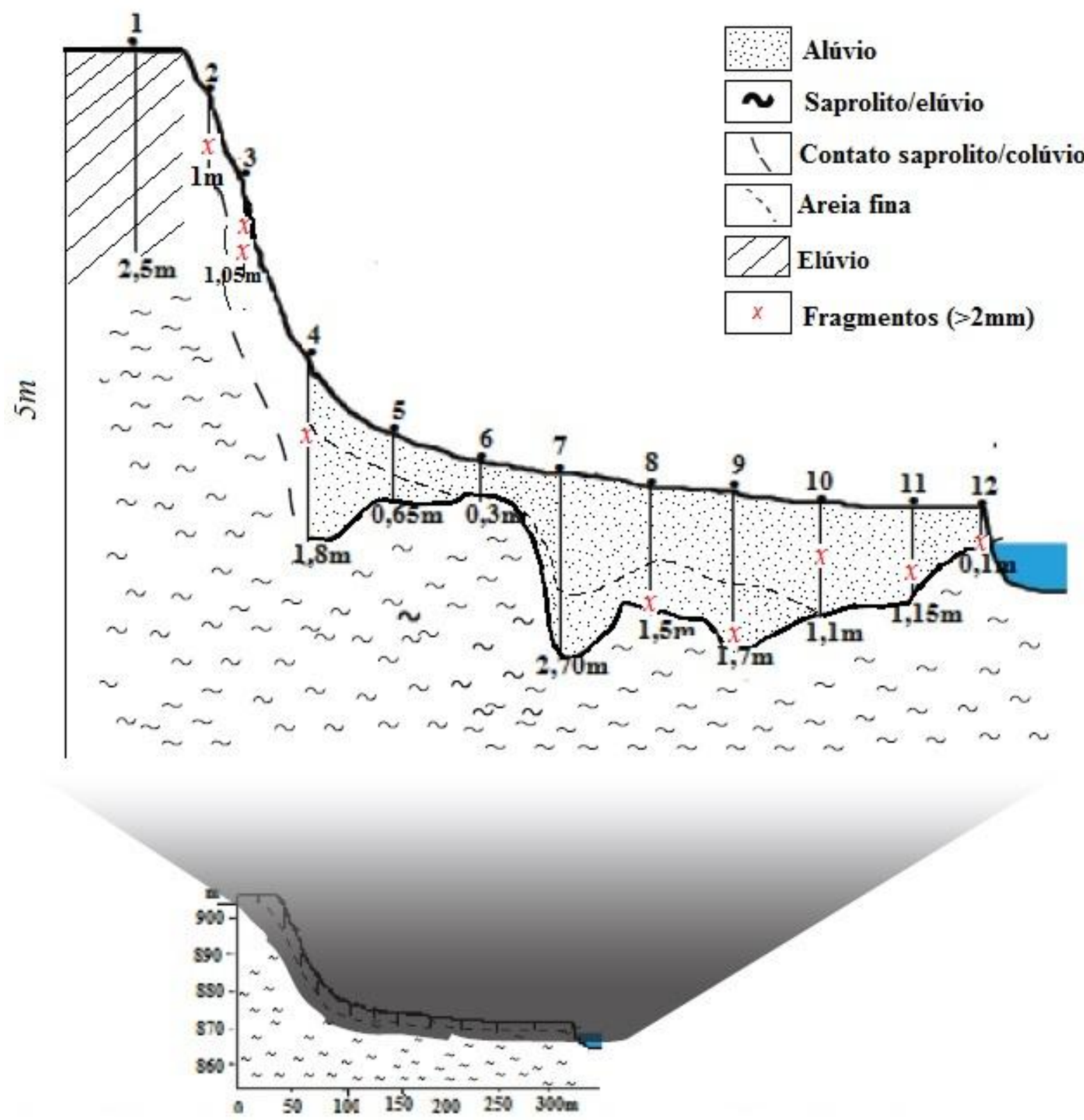

Figura 17 - Perfil lateral da E2

Foi observado que as curvas granulométricas desses três pontos da encosta, da superfície até $1,5 \mathrm{~m}$ de profundidade, também se agrupam numa tendência, contudo, muito próximas do que se classificou como saprolito. Portanto, todos os pontos coletados no topo da encosta, serão considerados como elúvio, devido não terem sofrido nenhum transporte. Pelo fato das curvas apresentarem três limites bem definidos, foi entendido que este material acima do nível dos saprolitos, seja composto por sedimentos transportado por gravidade, das porções superiores da encosta. Isto pôde ser observado também pelas averiguações no campo, já que 
neste mesmo espaçamento foram encontradas concentrações de fragmentos maiores que $2 \mathrm{~cm}$, de material bastante friável, advindo do próprio saprolito. Portanto considerou-se que os materiais da superfície até a profundidade de $0,9 \mathrm{~m}$, dos pontos P2 e P3 sejam colúvios.

No momento em que se toma a porção plana dessa topossequência em estudo, as curvas granulométricas tendem para um novo modelado, desta vez bem diferente do elúvio e colúvio, apontados anteriormente. As diferenças se dão claramente pelo despontamento da fração 0,1(areia fina), que não aparece ao longo da encotsa. As frações silte e argila se mantém altas, sendo que a partir do P10, já nas proximidades do ribeirão, esse diâmetro de partícula cai drasticamente. Ressalta-se que as tradagens, e logo, as coletas, ao longo do vale, alcançaram profundidades em sua maioria muito pequenas,e, portanto, esses resultados referem-se a parte mais superficial do solo, como se observa no desenho do perfil ( $\quad$ Figura 17).

Em relação ao material de fundo de vale, também é visível que a presença de areia fina é crescente a partir do P1, sendo que a partir do P4 aumenta na seguintes proporções: P4 (3,28), P6 (8,66), P7 (17,17), P9 (28,7), P10 (29,70), P11 (41,37). Neste caso, os únicos ponto que não se inseriram em ordem crescente foram somente o P8(14,19) e P12(17,29). Esta variação dos valores de areia fina, faz com que as curvas granulométricas do alúvio, mantenham um padrão, mas, com valores mais espaçados do que os que obtivemos para o elúvio e colúvio (Figura 16)

O único ponto fora desse padrão, foi o $\mathrm{P} 4$, localizado a $10 \mathrm{~m}$ do sopé da encosta, possivelmente área máxima de alcance do espraiamento dos sedimentos vindos da encosta, principalmente finos. Este ponto está representado no gráfico abaixo, onde é comparado com outro ponto de material aluvial da mesma encosta, só que de comportamento padrão.

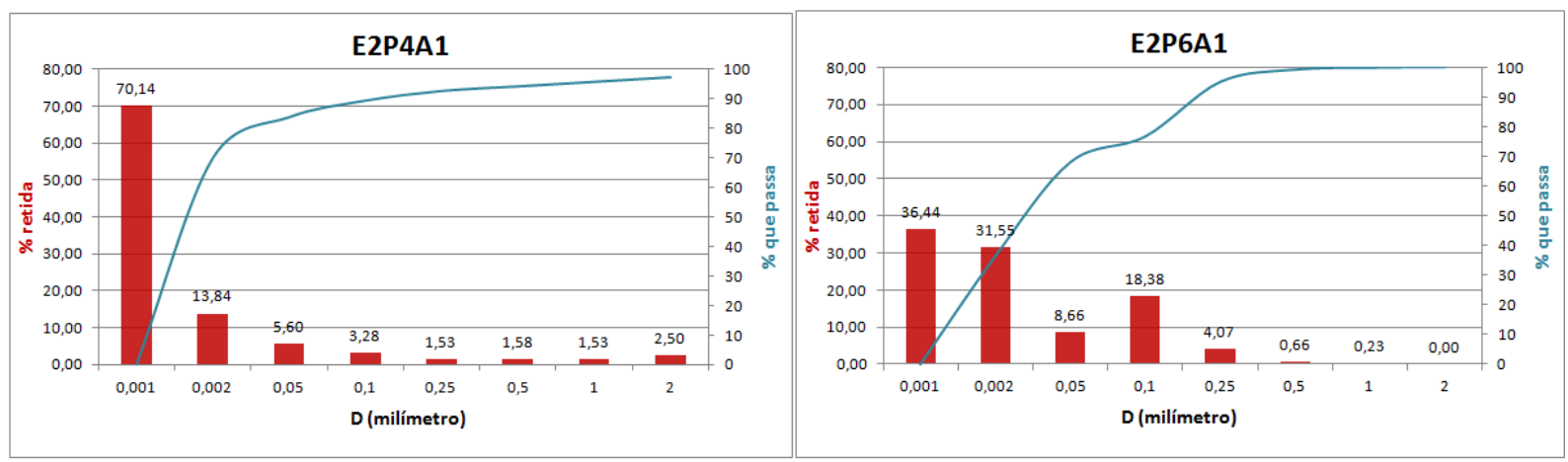

Figura 18 - Gráfico de comparação de comportamento de alúvios da E2 
No trinagulo da E2 (Figura 19), como já levantado, tem uma área de fundo de vale mais extensa onde foram coletadas a maioria das amostras. Por sua vez, essa porção sofreu recebimento de grande quantidade de finos de areia, que caracteriza esse alúvio como arenoargilosos, areno-argiloso-siltoso, e argilo-siltoso. O P4, como já destacado, apresentou mais influência dos sedimentos de encosta e classifica-se aqui como argiloso.

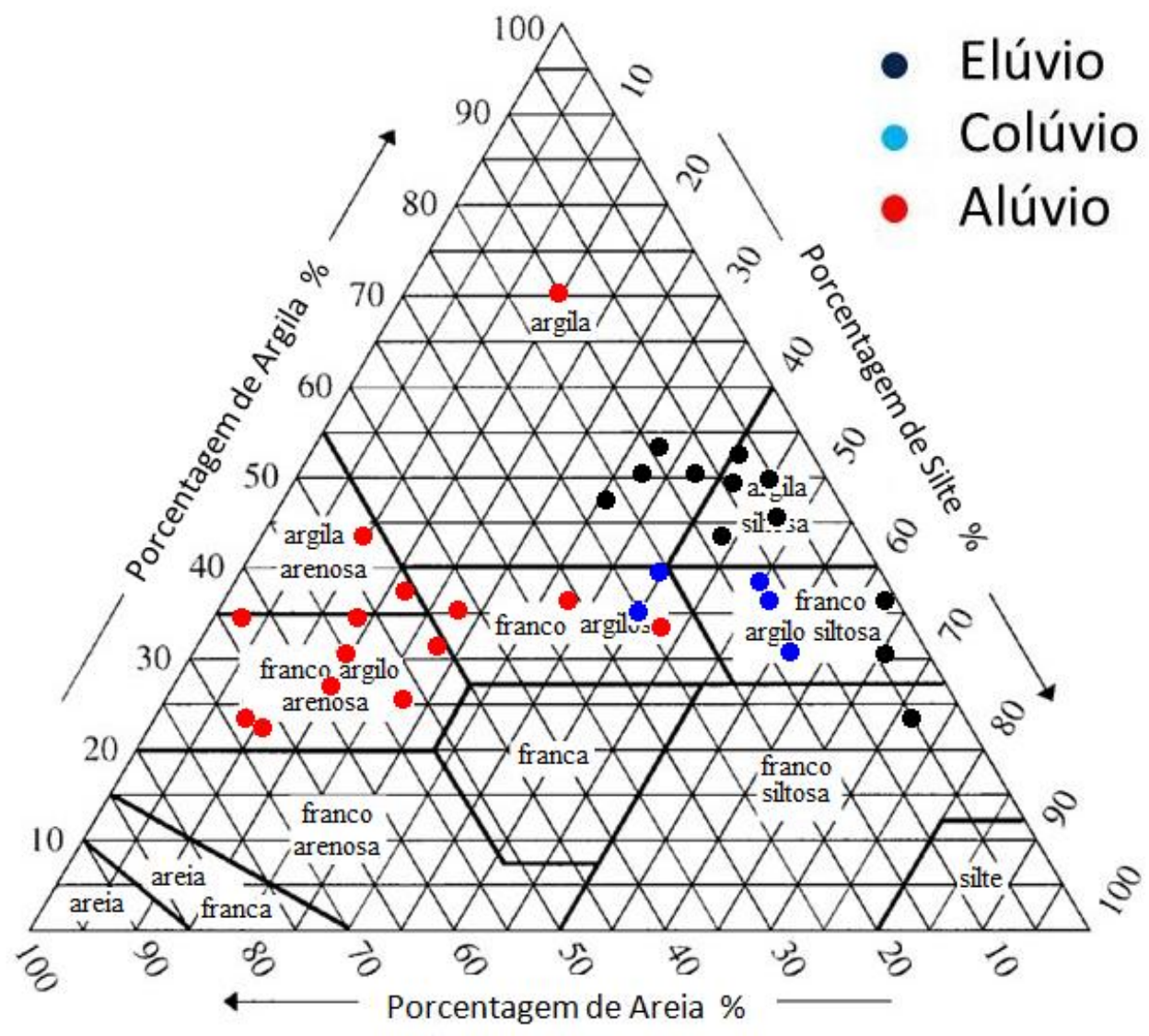

Figura 19 - Triangulo granulométrico E2

Teste de cisalhamento - E2

Foram feitos ensaios para obtenção da curva de ruptura para os solos da porção média e topo da concavidade aberta como pode ser observado na Figura 20. 

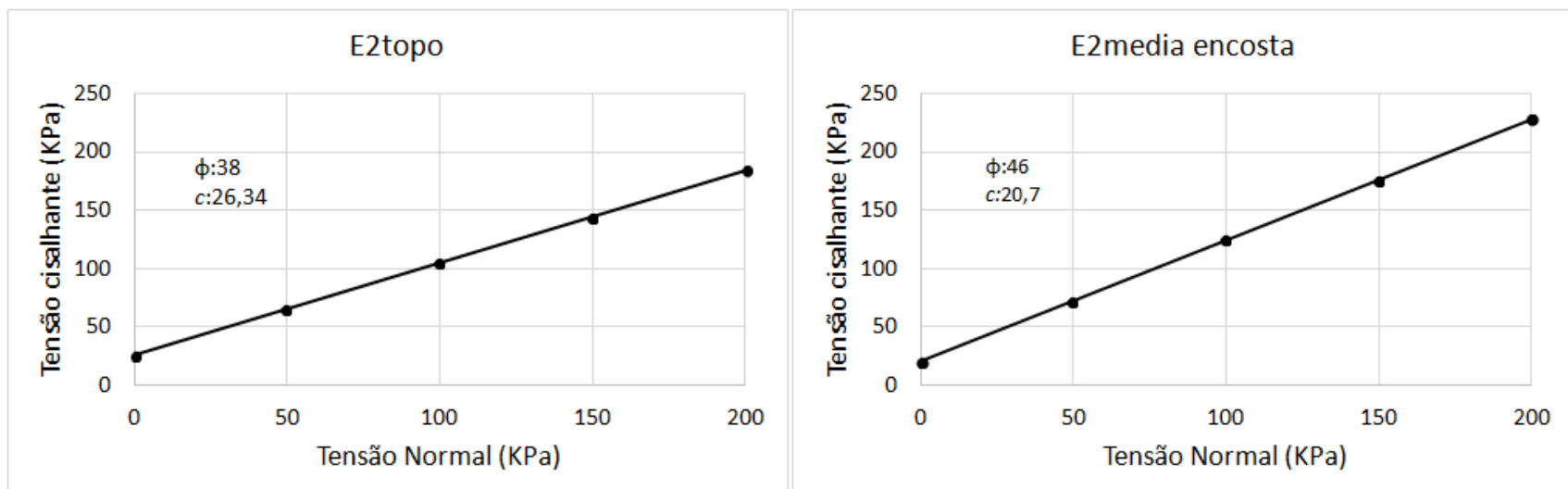

Figura 20 - Gráficos da curva de ruptura das amostras da E2

Apenas ao conteúdo de areia que foi detectado nos pontos P7 e P10 da E1, e nos pontos P12, P11,P10 da E2, é que pode-se conferir aos solos da fazenda Buraco, um comportamento arenoso, sob o ponto de vista geotécnico. A resistência dos materiais desses pontos, podem ser demonstradas pelos ensaios das amostras coletadas no fundo de vale Figura 21, que apresentaram angulo de atrito $33^{\circ}$ e coesão $9,84 \mathrm{kPa}$..

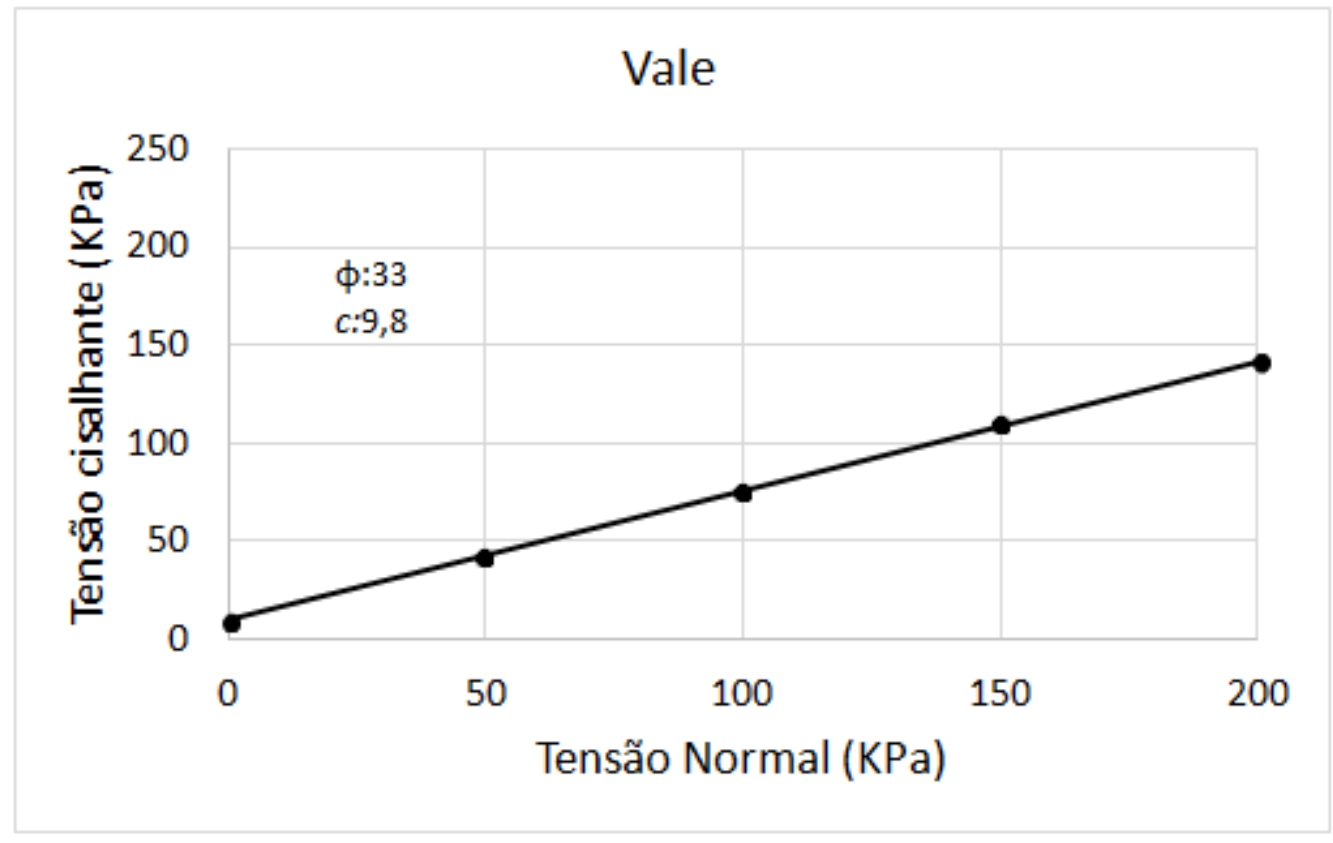

Figura 21- Gráfico da curva de ruptura encontrado na área de vale

Apesar da resistência ao cisalhamento não ser comumente aplicada às áreas planas, a informação de baixa coesão observada no vale, é provavelmente consequência da maior presença de areia 


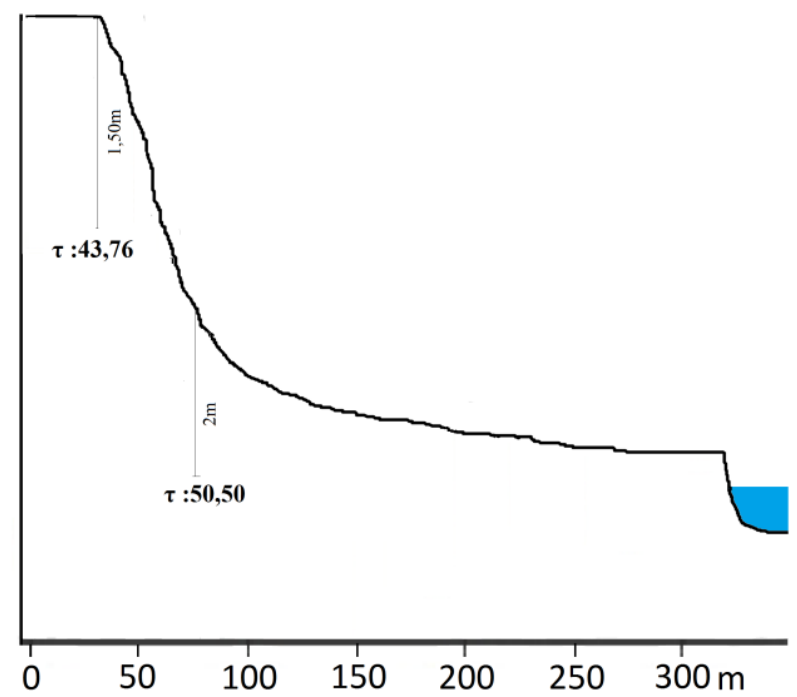

Figura 22 - Resistência ao cisalhamento na E2

As parcelas de resistência oferecidas pela E2 média encosta em comparação com as oferecidas pela E1 média encosta, são mais altas para coesão, no entanto, um pouco menores para ângulo de atrito . Isso pode se dever ao fato de que a descida e doposição de colúvios ao longo da E1 mostra-se mais ativa, compondo a média e baixa porção da encosta com detritos, como foi observado em campo. Somado a isso, o P7 da E1 foi um dos pontos com o maior quantitativo de areia, observados para esta encosta.

O aumento dessa fração mais grosseira pode conferir ao solo maior parcela de resistência por atrito, principalmente por que esses depósitos de encosta apresentam partículas mais angulosas devido o rolamento por gravidade, como foi demonstrado por Caldeira, (2015) em estudo morfoscópico feito para os colúvios da E1. 


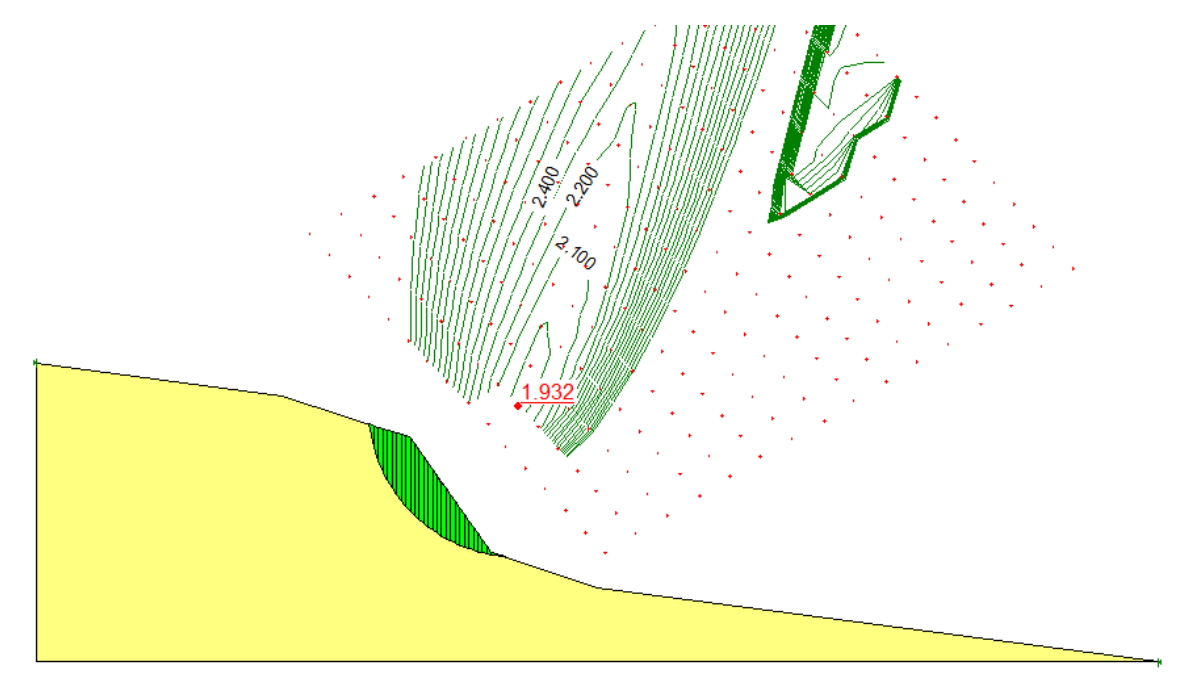

Figura 23- Fator de segurança da E2

Encosta convexo-retilínea - E3

O ponto 1 (topo) pôde ser investigado até a profundidade de 1m (Figura 24). Perfil com solo argiloso de cor amarela (10YR5/6) e alta concentração de cascalhos. Os pontos 2, 3, 4, alta, média, e baixa encosta, respectivamente, são porções da encosta com solo variando entre Amarelo e Glei e com muitos cascalhos. O ponto 5 assemelha-se aos anteriores, sendo o último ponto antes do rio.

E3

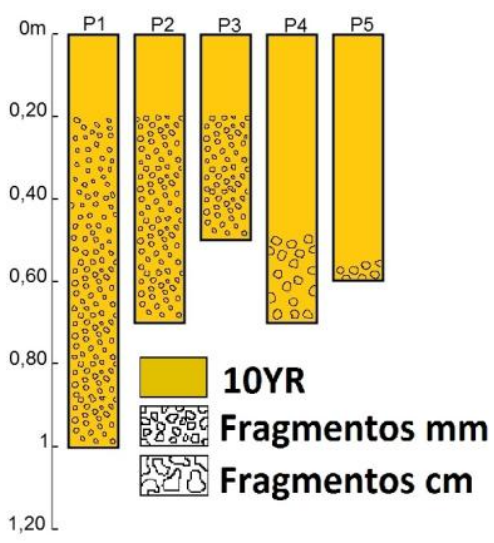

Figura 24 - Perfil vertical da E3 
A encosta convexa não apresentou variação significativa de granulometria ao longo dos pontos coletados (Figura 25

Figura 25). Essa encosta é parte residual do relevo, onde permanecem mais preservadas as características da rocha, nesse sentido a porção mais intemperizada desse material, em que foi possível tradar e fazer coletas, demonstrou predominância de site e argila em todos os pontos, como pode ser observado no gráfico abaixo.

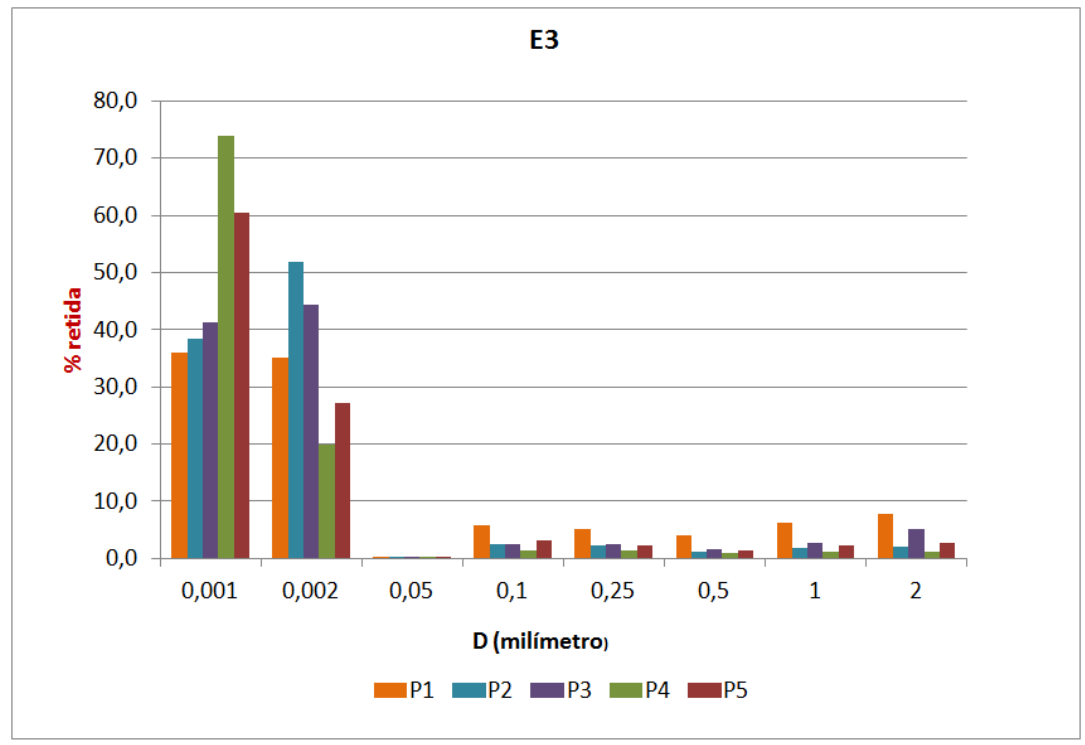

Figura 25 - Gráfico Histograma da granulometria da E3
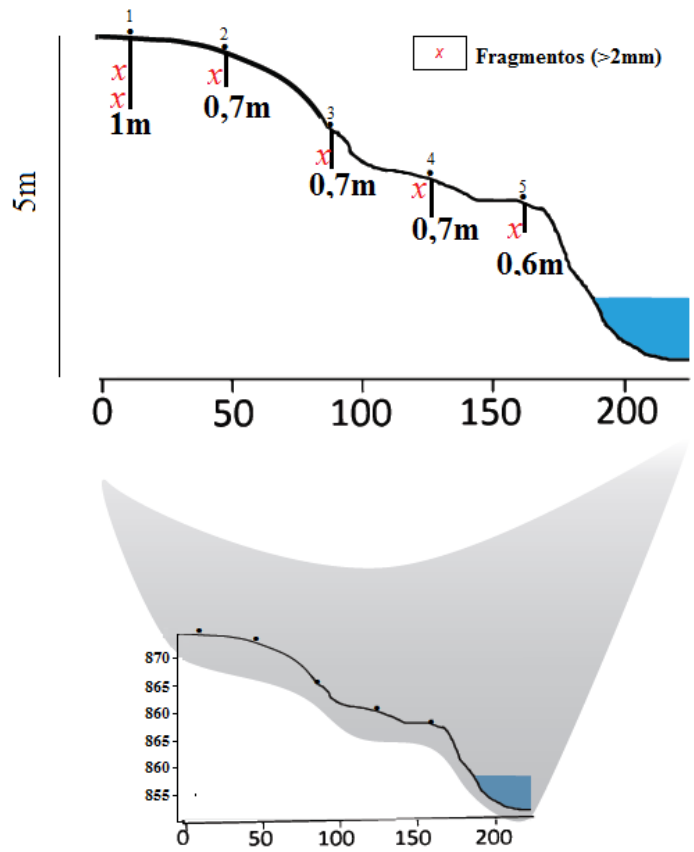
Figura 26 - Perfil lateral da E3

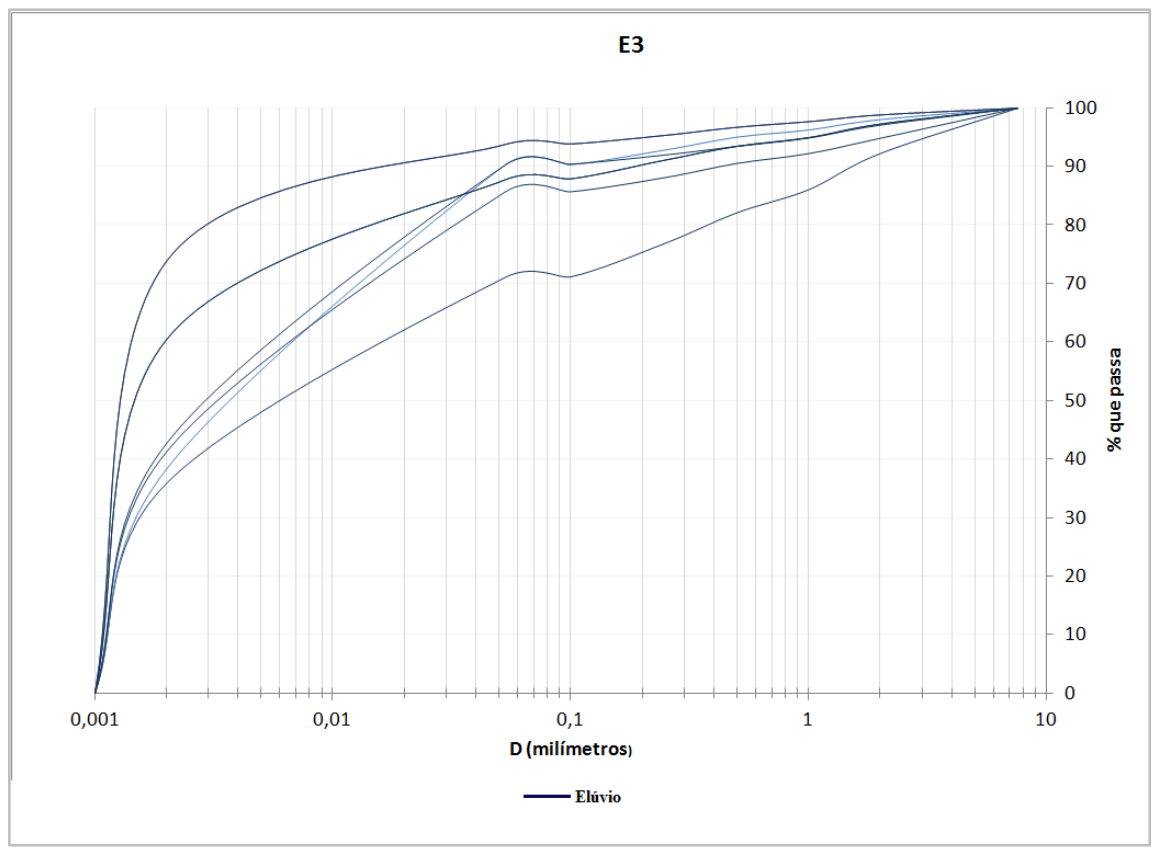

Figura 27 - Gráfico granulométrico da encosta convexa - E3

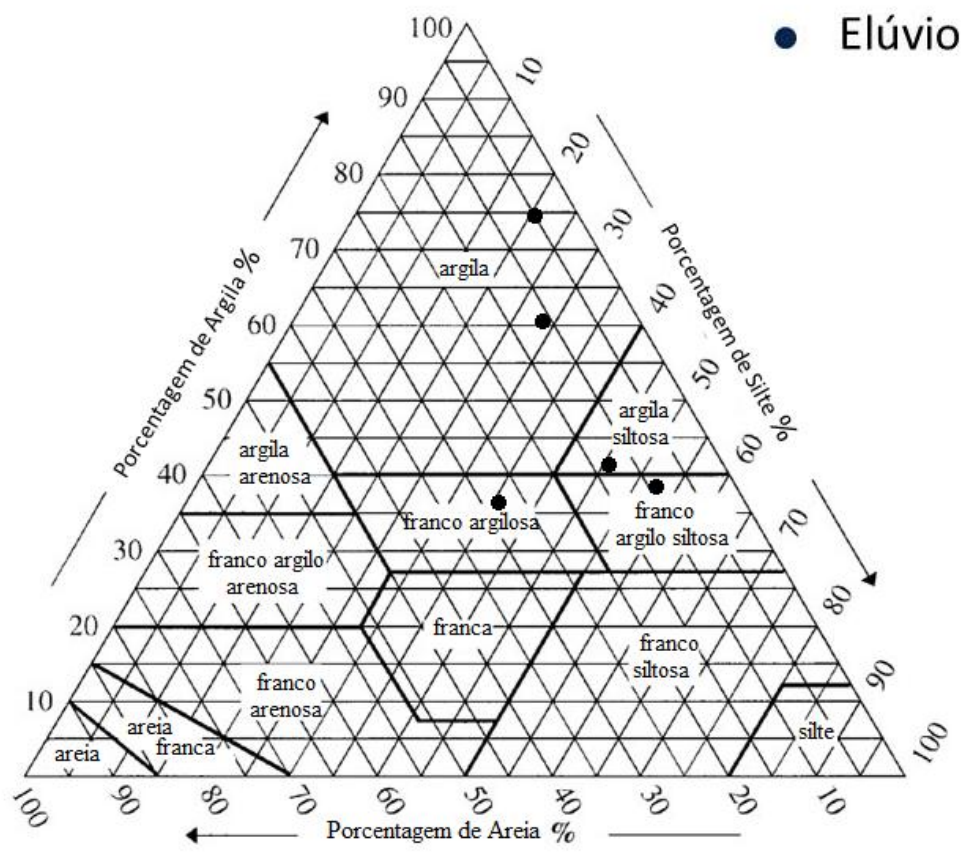

Figura 28 - Triangulo granulométrico da E3

A classificação pelo triangulo granulométrico, dispersa as amostras nas frações argilosiltosas e silto-argilosas. 
Ensaios Geotécnicos - E3

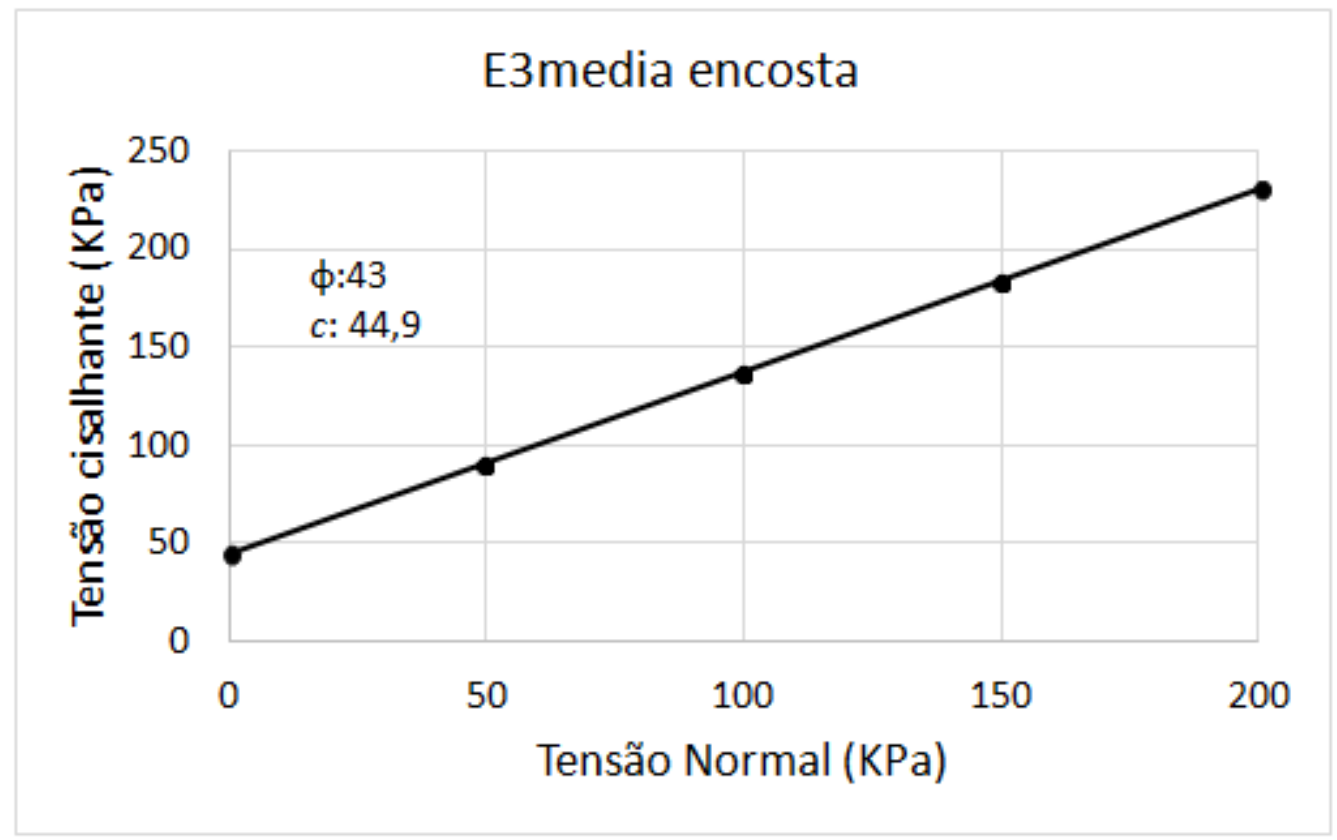

Figura 29 - Gráfico das curvas de ruptura da E3

A curva de ruptura da E3 (Figura 29) apresenta valores significativamente mais altos de tensão cisalhante para ambas as 3 tensões normais aplicadas, conferindo a esta encosta o maior valor de resistência ao cisalhamento ( Figura 30).

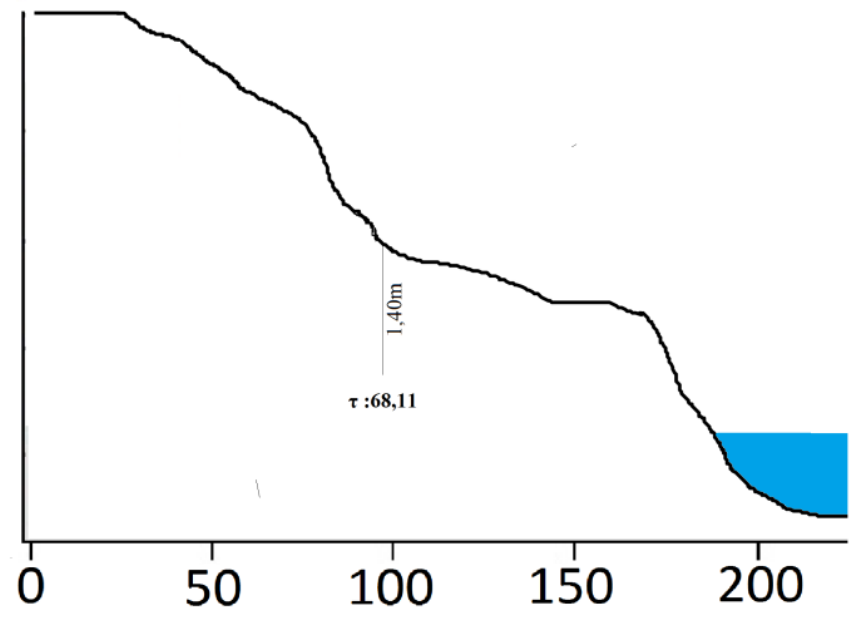


Figura 30 - Resistência ao cisalhamento na E3

Fator de Segurança - E3

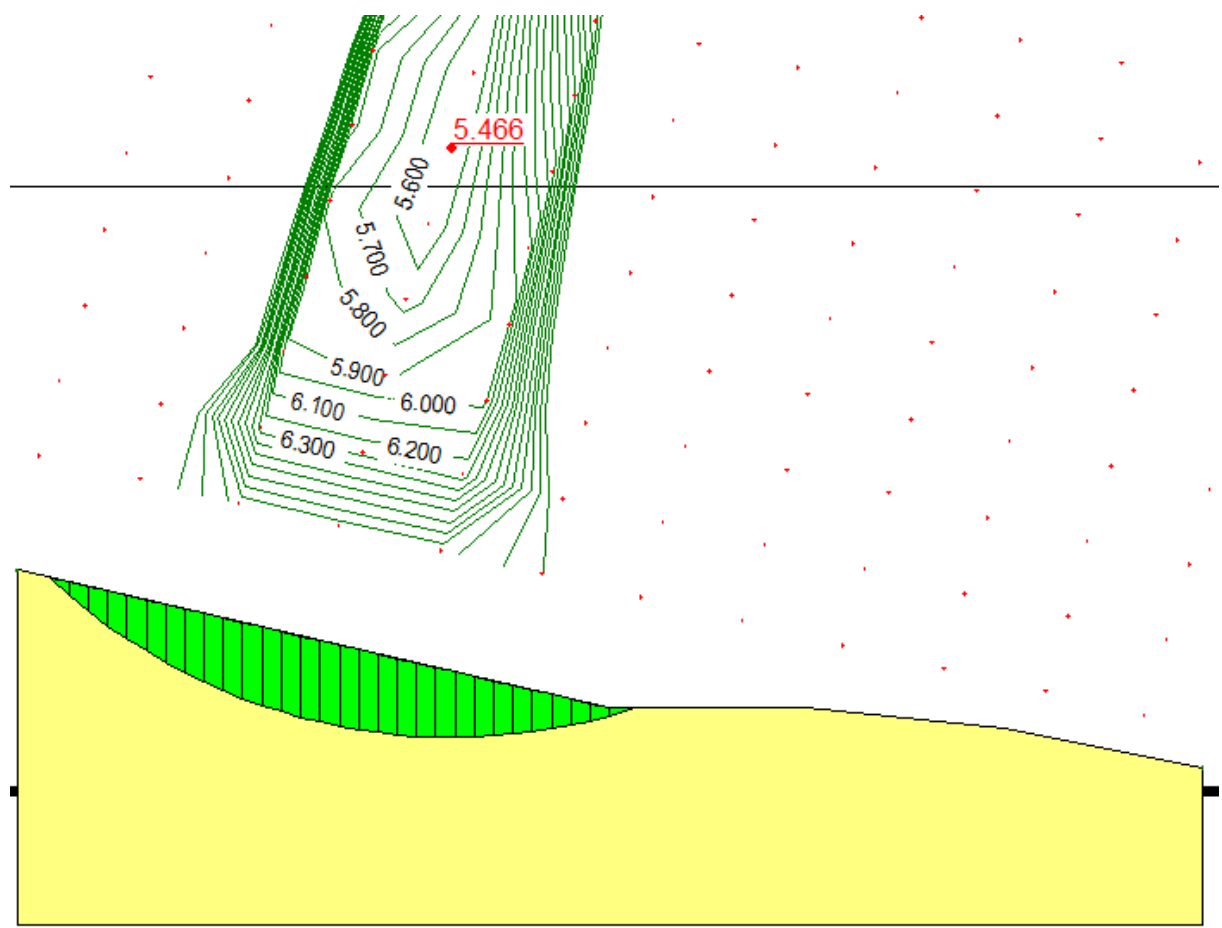




\section{CONCLUSÕES}

A estabilidade dos materiais averiguada por esta pesquisa admite dizer que a ocorrência de fenômenos de deslizamento na bacia do ribeirão Contagem não estão predominantemente ligadas às características mecânicas dos materiais que as compõe. O que as análises geomorfológicas, por sua vez, nos intuem, é a existência pretérita da condição de eventos mais fortes que geraram as cicatrizes e deposições, observadas atualmente. Distinguem-se na área de estudo, três patamares de deposição bem delimitados que conferem comportamentos distintos para cada porção da encosta e fundo de vale. Obtiveram-se altos valores de resistência ao cisalhamento para todas as porções das encostas, sendo que a encosta convexo-retilínea apresentou o maior. Os testes revelaram baixa coesão e ângulo de atrito na área do vale. As curvas de ruptura apresentaram altas tensões cisalhantes suportadas pelos solos da encosta convexa, em detrimento das demais. A granulometria de toda a área é essencialmente argilosa, com exceção da área deposicional. $\mathrm{Na}$ análise dos sedimentos observou-se ausência de vestígios claros de uma estratificação causada por depósito de movimento de massa, que pode já ter sido retirado recentemente devido a forte atividade erosiva observada na área. As análises demonstraram que os depósitos de sedimentos tem influência fluvial, na área de estudo. Ressalta-se a importância de estudos de datação para a comprovação destas análises. 


\section{REFERÊNCIAS BIBLIOGRÁFICAS}

ALIMOHAMMADLOU, Y; NAJAFI, A; YALCIN, A.Landslide process and impacts: A proposed classification method. Catena. 2012.

Bommer, JJ \& Rodriguez, CE. Earthquake-induced landslides in central America, ENGINEERING GEOLOGY, Vol: 63, Pages: 189-220, ISSN: 0013-7952, 2002.

BRAGA, L. Mapeamento de Feições Erosivas e Análise de Fatores Controladores da Erosão na Bacia Hidrográfica do Ribeirão Contagem - DF. Monografia. Departamento de Geografia. Universidade de Brasília. Brasília 2013.

CAMPOS, JOSÉ ELOI GUIMARÃES ; DARDENNE, MARCEL AUGUSTE ; FREITASSILVA, FLAVIO HENRIQUE ; MARTINS-FERREIRA, MARCO ANTÔNIO CAÇADOR . Geologia do Grupo Paranoá na porção externa da Faixa Brasília. Brazilian Journal of Geology, v. 43, p. 461-476, 2013.

EMBRAPA. Levantamento dos solos do distrito Federal. Rio de Janeiro, 455 p., Boletim Técnico 53. 1978

HERATH, S.; WANG, Y. Case Studies and National Experiences. In: Sassa, K., Canuti, P. (Eds.), Landslides — Disaster Risk Reduction. Springer Verlag, Berlin Heidelberg, pp. 475497. 2009.

KJEKSTAD, O.; HIGHLAND, L. Economic and social impacts of landslides. In: Sassa, K., Canuti, P. (Eds.), Landslides — Disaster Risk Reduction. Springer Verlag, Berlin Heidelberg, pp. 573-587. 2009.

MARTINS, E.S. et. al. Caracterização Geomorfológica In FONSECA, Fernandes. (Org.). APA de Cafuringa: a última fronteira natural do Distrito Federal. Brasília, DF: SMARH-D F - SEMARH, (2005).

SANTOS, R. Estudo dos Controles Morfométricos à feições erosivas na Bacia Hidrográfica do Ribeirão Contagem. Monografia. 2013. 
TERZAGHI, K. Soil Mechanics in action. Cic. Eng., 29: 69-70. 1959.

TRICART, J. Landforms of the humid tropics, forests and savannas. Longmans, London, 306 pp. 1972.

VARNES, D. J. Slope movement types and processes. In: Special Report 176: Landslides: Analysis and Control (Eds: Schuster, R. L. \& Krizek, R. J.). Transportation and Road Research Board, National Academy of Science, Washington D. C., 11-33. 1978.

VASCONCELOS, V.; CARVALHO JUNIOR, O.A; MARTINS, E.S; COUTO JUNIOR,A.F; GUIMARÃES, R.F; GOMES, R.A.T. Sistema de classificação geomorfométricabaseado em uma arquitetura sequencial em duas etapas: árvore de decisão e classificador espectral, no Parque Nacional Serra da Canastra. Revista Brasileira de Geomorfologia, v.13,n.2, p.171$186,2012$. 


\section{REFERÊNCIAS BIBLIOGRÁFICAS}

BORGES, R. O; CASTRO, S. S. Utilização de Geotecnologias para o mapeamento das feições geomorfológicas da bacia hidrográfica do ribeirão João Leite, GO. VI Simpósio Nacional de Geomorfologia. 2006.

BRAGA, L. Mapeamento de Feições Erosivas e Análise de Fatores Controladores da Erosão na Bacia Hidrográfica do Ribeirão Contagem - DF. Monografia. Departamento de Geografia. Universidade de Brasília. Brasília 2013.

BRESSANI. A. L; BERTUOL. F. Alguns Escorregamentos do RS e de SC e a Avaliação de Susceptibilidade de Risco de Encostas. In:_ LACERDA. A W. (Org).

CAMAPUM DE CARVALHO, J. et al. Proposta de Uma Nova Metodologia para ensaios de Sedimentação. In: 30a Reunião Anual de Pavimentação Salvador, BA; ABPV, 520-531 p. 1996.

CARVAlHO, J. C. Processos erosivos no Centro-Oeste Brasileiro. Brasília: Universidade de Brasília: FINATEC, 2006.

CHAGAS, C.S.; FERNANDES FILHO. E.I.; BHERING, S.B. Relação entre atributos do terreno, material de origem e solos em uma área no noroeste do estado do Rio de Janeiro. Sociedade \& Natureza. v. 25, p. 147-162, 2013.CHRISTOFOLETTI, Antonio. O canal fluvial. In:__. Geomorfologia Fluvial. 1. Ed. v. 1. São Paulo: Edgard Blücher, 1974. . Geomorfologia. 2. Ed. São Paulo: Edgard Blücher, 1980.

COELHO NETTO, A. L.; FERNANDES, N. F., DANTAS; M. E., DIETRICH, W. E.;MONTGOMERY, D. R., DAVIS; J.C., PROCTOR, I.;VOGEL, J. \& SOUTHIN,J. Evidences of two Holocene erosion-sedimentation cycles in ----- SE.Brazil: stratigraphy and stratigraphy inversion”. In: Abstracts of the $14^{\text {th }}$ International Sedimentological Congress, Recife, p.29-30, 1994.

COElho NETTO, A. L. "Evolução de Cabeceiras de Drenagem no Médio Vale do Rio Paraíba do Sul (SP/RJ): a Formação e o Crescimento da Rede de Canais sob Controle Estrutural”. RBG. Ano 4. N², p. 69 -100, 2003 a. 
COELHO NETTO, A. L. Hidrologia de Encosta na Interface com a Geomorfologia. Geomorfologia - uma Atualização de Bases e Conceitos. Org. GUERRA, A.J. T. CUNHA, S. B. da. 5 ${ }^{\text {a }}$ Ed. Rio de Janeiro: Bertrand Brasil, P. 93-148, 2003 b.

COELHO NETTO, A.L.; AVELAR, A. S.; FERNANDES, M. C.; LACERDA, W. A. Landslide Susceptibility in a Montainous Geoecosystem, Tijuca Massif, Rio de Janeiro: The Role of Morphometric Subdivision of the Terrain. In: GEOMORPHOLOGY. 2006.

COELHO NETTO, Ana Luiza ; AVELAR, André de Souza ; SATO, Anderson Mululo ; Dias, M. A. ; SCHLEE, Mônica Bahia ; NEGREIROS, André Batista de . Vulnerabilidade em Geoecossistemas Montanhosos e Desastres Causados por Deslizamentos na Interface Floresta-Urbana: controles geológicos, geomorfológicos e geoecológicos.. In: Willy Alvarenga Lacerda; Ennio Marques Palmeira; Ana Luiza Coelho Netto; Mauricio Ehrlich. (Org.). Desastres Naturais - Susceptibilidade e Riscos Mitigação e Prevenção Gestão e Ações Emergenciais. Rio de Janeiro: , 2012, v. 1, p. 63-80.

CUNHA. 1991.

CUNHA, S. B.; GUERRA, A. J. T. A. Questão ambiental: Diferentes abordagens. 4a edição. Rio de Janeiro, Bertrand Brasil, 2008.

Desastres Naturais: susceptibilidade e riscos, mitigação e prevenção, gestão e ações emergenciais.Rio de Janeiro: COPPE/UFRJ, 2012.

DIKAU, R., BRUNSDEN, D., SCHROTT, L. \& M.-L. Ibsen (Eds.). Landslide Recognition. Identification, Movement and Causes. Wiley \& Sons, Chichester. 1996.

DUNN, S. I.; ANDERSON, R. L.; KIEFER, W. F. Funtamentals of Geotechnical Analysis. Wiley. 1980.

DUNNE, T. \& BLACK, R.D. “An experimental investigation of runoff processes inpermeable soils. Water Research 6, 478-490. 1970.

$\mathrm{EPOCH}_{2}$ The temporal occurrence and forecasting of landslides in the European community (Ed: Flageollet, J. C.). Contract No. 90 0025, 3 Volumes.1993

FERNANDES, N.F. \& AMARAL, C. Movimentos de Massa: uma abordagem geológicogeomorfológica. In: Geomorfologia e Meio Ambiente, A. P. T. GUERRA e B. CUNHA (orgs.), Rio de Janeiro, Ed. Bertran Brasil, 1997, Cap.3, pp. 123-194. 
FIORI, A. P.; CARMIGNANI, L. Fundamentos de mecânica dos solos e das rochas: aplicação na estabilidade de taludes. Editora UFPR. 550p. 1997.

FUTAI. M. M et al. Infiltração e estabilidade de encostas em condições não saturadas in CARVALHO. J. C. Tópicos sobre infiltração: teoria e prática aplicados a solos tropicais. Brasília, Faculdade de Tecnologia, 2012.

GAN, J. K. M. (1986). Direct Shear strength testing of unsaturated soils. $587 \mathrm{fl}$. Dissertação (Mestrado), Department of Civil Engineering, University of Saskatchewan, Canadá.

HACK, J.T \& GOODLET, J. G. Geomorfology and forest ecology of a mountain region in the Central Appalachians. U.S. Geol. Survey Prof. Paper 347 - 66p,1960.

HERATH, S.; WANG, Y. Case Studies and National Experiences. In: Sassa, K., Canuti, P. (Eds.), Landslides — Disaster Risk Reduction. Springer Verlag, Berlin Heidelberg, pp. 475497. 2009.

HUTCHINSON， J. N. General Report: Morphological and geotechnical parameters of landslides in relation to geology and hydrogeology. Proceedings, Fifth International Symposium on Landslides (Ed: Bonnard, C.), 1, 3-35. Rotterdam: Balkema.1998.

INSTITUTO DE PESQUISAS TECNOLÓGICAS (IPT). Estudo das instabilizações de encostas da Serra do Mar na região de Cubatão objetivando a caracterização do fenômeno "corrida de lama" e prevenção de seus efeitos. São Paulo:185 p. (IPT-relatório n. 26258). 1989.

KJEKSTAD, O.; HIGHLAND, L. Economic and social impacts of landslides. In: Sassa, K., Canuti, P. (Eds.), Landslides - Disaster Risk Reduction. Springer Verlag, Berlin Heidelberg, pp. 573-587. 2009.

KOBIYAMA, Masato, et al. Prevenção de desastres naturais - conceitos básicos. Curitiba : Ed. Organic Trading, 2006.

KUKEMILKS, K.; SAKS, T. Landslides and gully slope erosion on the banks of the Gauja River between the towns of Sigulda and Lìgatne. Estonian Journal of Earth Sciences, ed.62. 2013.

LADE, V. P. The mechanics of surficial failure in soil slopes. Engineering Geology. 2010. 
LEAL, R \& ELLIOT, W. Erodibility and erosivity. Soil erosion research methods. 2 ed. (ed. R. Lal). Flórida: St Lucie Press, USA, p. 181-208. (1994).

MACHADO, M.B. \& MOURA, J.R.S. A Geomorfologia e a sedimentação Quaternária no médio vale do rio Casca, MG. Anais, Congresso. Bras. Geologia, Salvador, vol.4: 1433-1441. 1982.

MARTINS, E.S. et. al. Caracterização Geomorfológica In FONSECA, Fernandes. (Org.). APA de Cafuringa: a última fronteira natural do Distrito Federal. Brasília, DF: SMARH-D F - SEMARH, 2005.

MEIJERINK, A.M.J. Data acquisition and data capture through terrain mapping units. ITC Journal, Wagenigen, V.1988, n 1, p. 23-44, 1988.

MEIS, M.R.M. \& MONTEIRO, A.M.F. Upper Quaternary rampas: Doce river valley, SE Brazilian Plateau. Zeit. Geomorph, 23: 132- 151. 1979.

MITCHEL, J. K.; SOGA, K. Fundamentals of soil behavior Third Edition. Wiley, New York. 2005.

MOURA, J.J.L.S; MEIS, M.J.L.M. Litoestratigrafia preliminar para os depósitos de encosta do quaternário Superior do Planalto SE do Brasil (MG-RJ). Revista Brasileira de Geociências. 1980

MUCHER, H.; STEIJN, H.; KWAAD, F. Colluvial and Mass Wasting Deposits. (capitulo 3) In STOOPS, G.; MARCELINO, V.; MEES, F. Interpretation of Micromorphological Features of Soils and Regoliths. Elsevier. 2010.

NIZEYIMANA, E. \& BICKI, T.J. Soil and soil-landscape relationships in the North Central region of Rwanda, East-Central Africa. Soil Sci., 153:225-236, 1992.

OLIVEIRA, B. E. N. (2011). Mapeamento, Identificação e Análise dos Fatores Relacionados aos Processos Erosivos no Distrito Federal (DF) - Ênfase nas Voçorocas. (Dissertação de Mestrado em Engenharia Florestal), Publicação PPGEFL. DM-169/2011 Programa de Pó Graduação em Engenharia Florestal, Universidade de Brasília, 2011.

OLIVEIRA, B. E. N. Mapeamento, Identificação e Análise dos Fatores Relacionados aos Processos Erosivos no Distrito Federal (DF) - Ênfase nasVoçorocas. (Dissertação de Mestrado em Engenharia Florestal), Publicação PPGEFL. DM-169/2011 Programa de Pó Graduação em Engenharia Florestal, Universidade de Brasília, 2011. 
PALMIERI, FRANCESCO; LARACH, I. O. J. Pedologia e geomorfologia. In: GUERRA, T. J.A; LARACH, I. Geomorfologia e Meio ambiente. Editora Bertran, Brasil. 1996.

QUEIROZ-NETO, P.J. Análise estrutural da cobertura pedológica: uma experiência de ensino e pesquisa. In: Revista do Departamento de Geografia, 15, 77-90 p. 2002.

QUEIROZ-NETO, P.J. Relações entre as vertentes e os solos: Revisão de conceitos. Revista Brasileira de Geomorfologia. v. 12, n³. 2011.

REATTO, A; MARTINS, E.S. Classes de solo em relação aos controles da paisagem do Bioma Cerrado. In: SCARIOT, A.; SOUZA-SILVA, J.C.; FELFINI, J.M. Cerrado: Ecologia, Biodiversidade e Conservação. ed 1. Brasília-DF: Ministério do Meio Ambiente, p. 47-59. 2005.

RESENDE et al. Pedologia: base para distinção de ambientes. 2.ed. Viçosa: NEPUT, 1997. $367 \mathrm{p}$.

RIGO, M.L. Resistência ao Cisalhamento Residual de Alguns Solos Saprolíticos de Basalto do Estado do Rio Grande do Sul. Dissertação de Mestrado. PPGEC/UFRGS, Porto Alegre. 134p. 2000.

SANTANA, R. G.; COUTINHO, R. Q. Análise de Soluções de Engenharia para contenção em encostas ocupadas na Região Metropolitana do Recife-PE. In: XIII COBRAMSEG, Curitiba. Vol 4. 2006.

SANTOS, H. G. dos; JACOMINE, P. K. T.; ANJOS, L. H. C. dos; OLIVEIRA, V. A. de; OLIVEIRA, J. B. de; COELHO, M. R.; LUMBRERAS, J. F.; CUNHA, T. J. F. (Ed.). Sistema brasileiro de classificação de solos. 2 ed. Rio de Janeiro: Embrapa Solos, 2006. 306p.

SANTOS, R. Estudo dos Controles Morfométricos à feições erosivas na Bacia Hidrográfica do Ribeirão Contagem. Monografia. 2013.

SILVA, A. P. J. APOSTILA DE MECÂNICA DOS SOLOS. Universidade Potiguar. Curso de engenharia civil. 2009.

TERZAGHI, K. Mechanism of landslides, in Application of Geology to Engineering Practice, Berkey Vol., Geological Society of America, p.83-123. 1950.

VARNES, D. J. Slope movement types and processes. In: Special Report 176: Landslides: Analysis and Control (Eds: Schuster, R. L. \& Krizek， R. J.). Transportation and Road Research Board, National Academy of Science, Washington D. C., 11-33. 1978. 
WOLLE, C. M. Análise dos escorregamentos translacionais numa região da Serra do Mar no contexto de uma classificação de mecanismos de insabilização de encostas. Tese Doutorado em Engenharia Civil, Escola Politécnica da Universidade de São Paulo, São Paulo. 1988.

XAVIER, F.V.; CUNHA, K.L.; SILVEIRA, A.; SAlOMÃO, F. X. T. Análise da suceptibilidade à erosão laminar na bacia do Rio Manso, Chapada dos Guimarães, MT, Utilizando Sistemas de Informação Geográfica. Revista Brasileira de Geomorfologia, v. 11. 2010. 
